\title{
Wisdom in Old English Literature and The Lord of the Rings
}

\author{
Kai Friedhoff
}

\section{Introduction}

\author{
"There is nothing like looking, \\ if you want to find something." \\ (The Hobbit 69)
}

"All that is gold does not glitter, / Not all those who wander are lost." This is the beginning of a famous poem from J. R. R. Tolkien's The Lord of the Rings, appearing in a letter from Gandalf to Frodo in which the wise wizard reveals Strider's true identity to the hobbits (169-70). While the first line offers much room for interpretation, I would like to draw attention to the second line of the poem where the act of wandering is described as a deliberate and purposeful activity. Goethe once said that he learned by the act of wandering what he did not learn in the conventional way ("Was ich nicht erlernt hab / Das hab ich erwandert," qtd. in Kimura 14) ${ }^{1}$ and this remark is analogous to Bilbo and Frodo who return somewhat wiser from their journeys. The image of wandering and roads is very present in The Lord of the Rings and it functions not only as a metaphor for life as such but also as a metaphor for the acquisition of wisdom, with characters progressing on their earthly roads of exploration, gaining ever more experience and insight along the road. This connection is brought out in Frodo's name, which

\footnotetext{
1 A related form is the participle bewandert "experienced, skilled."
} 
derives from the Old English word frod, translated by Tolkien as "wise by experience" in a letter to Richard Jeffery (Letters 224). Since the name Sam evinces similar connections to the concept of wisdom-it derives from Old English samwis "halfwise" (LotR 1136; App. F)—the notion of wisdom in Tolkien's mythology clearly deserves some attention.

The metaphor of the road and wandering, however, is not the only way of understanding wisdom in The Lord of the Rings. One could consider Tolkien's notion of wisdom as reliant on the different races in his created world, of which the Elves appear to be the wisest. Yet it is equally conceivable to see the author's notion of wisdom in The Lord of the Rings as primarily related to a firm rootedness in tradition and to the characters being intricately bound with earlier ages of Middle-earth. Given the fact that Tolkien spent his professional life delving into British and Scandinavian history and their literary legacies, this obvious connection between the wisdom of Tolkien's characters and their relation to the past makes it tempting to look at the medieval sources from which Tolkien took his inspiration for the creation of Middle-earth. The general influence of such sources on Tolkien's works is well-researched by now, most notably with Shippey's The Road to Middle-earth, which has been a cornerstone in the field for more than thirty years and provides a comprehensive guide to the medieval footprints in Tolkien's mythology. Specifically Anglo-Saxon imprints have been demonstrated by many critics to date. Honegger, for example, shows the relationship between historical Anglo-Saxons and Tolkien's Rohirrim ("The Rohirrim"). There is, however, still no contrastive approach to the literary representations of wisdom in The Lord of the Rings and Old English literature to my knowledge. Book-length studies are scarce and concerned with biblical parallels exclusively (e.g. Pollard; O'Day) and none of the main experts on Tolkien like Shippey or Flieger seems to have focused on this specific aspect. Mythlore and Tolkien Studies, two of the most renowned scholarly journals about the works of Tolkien, do not yield any promising articles either (Croft and Crowe). It would be interesting, however, to analyse the representation of wisdom in both The Lord of the Rings and its Old English sources, in order to find out in how far Tolkien's literary depiction of wisdom can be seen in the light of his scholarly, philological activities. Such an approach might not only shed some light on the notion of wisdom in one of the most famous pieces in world literature, but also help to better understand Tolkien's employment of medieval sources in general. It will be significant to look at the moments when the author breaks loose from these sources, and unearths some of his own philological considerations in the process.

The main argument of this paper is that Tolkien's representation of wisdom in The Lord of the Rings mirrors the author's love for his philological profession in times when philology started to play an increasingly declining role in British universities (Shippey, Road 1-31). Traditional knowledge, or ancient knowledge, seems to be the key ingredient to his characters' wisdom, and this wisdom can be 
recovered philologically via the study of age-old texts such as are found in AngloSaxon manuscripts today. On that basis, a general love for the old and a passion for rediscovering the wisdom of earlier days is a good way of understanding the term philology in this paper. However, Tolkien not only turns his main characters into philologists in the broadest sense, revaluing philological endeavours. His representation of wisdom can also be put into direct relation with his personal philological contemplations about the medieval literature he studied over the course of his career. In fact, it is via his representation of wisdom that one can see his reworking of the Northern theory of courage, the famous ideal that Germanic heroic literature like Beowulf has at its core. In this way, The Lord of the Rings turns into an extended literary commentary on the Old English poem: by emphasising the role of wisdom, which it celebrates as more important and desirable than an Old English heroism based on courage and glory on the battlefield, the novel reveals Tolkien's own perception of the Old English poem. By its link to tradition and former ages, the representation of wisdom refers back to the medieval material that served as a source of inspiration for Tolkien's own literary creations. Old English heroism thus dethroned, the main characters in The Lord of the Rings themselves become philologists. Gandalf, for instance, only understands about the Ring after filing through the ancient texts in the libraries of Gondor and both Bilbo and Frodo become compilers, scholarly chroniclers in a sense, after they return home from their adventures (Kraus). Tolkien's representation of wisdom is thus coupled with the old and traditional, to be gained by studying old texts, by learning from and about the past, and from the experiences of those having trodden similar roads a long time ago.

As a first step in this paper, I am going to provide an extensive overview of common representations of wisdom in Old English literature. This overview is intended to give a broad picture of what wisdom was associated with in Old English literature in general before we turn to Beownlf in particular as our main medieval source of comparison for the following sections. After all, Tolkien studied the poem his entire life and it might easily be the single most influential medieval inspiration for his writings. In a second step, I will briefly discuss the general role and influence of wisdom for the plot of The Lord of the Rings in order to touch on the interaction of wisdom with other, higher powers in Middle-earth. Moving then to our main analysis with a focus on Middle-earth, I will address the philological road to wisdom in the fourth section. In this first section, we are going to look at songs and stories as sources of ancient wisdom, and how the characters' own fictionalisations of their reality are attempts to chronicle their experiences for the benefit of later generations. The fifth section will be about information and counsel as the currencies of wisdom. It will show that The Lord of the Rings places more emphasis on strategy and tactics, on reflecting together in councils, which ultimately proves that wise characters in Tolkien's work choose and behave differently from the heroes from the Old English poem. The last section before the 
conclusion will look at the interplay of wisdom and heroism in The Lord of the Rings and Beowulf, illustrating that Tolkien's mythology demystifies the sort of heroism portrayed by the Old English hero, and that it is the wise characters of Middleearth who are glorified in his world.

\section{The Anglo-Saxon Road to Wisdom}

How would Anglo-Saxons define wisdom, and what kind of road would they point to? Wisdom being an abstract concept, it is difficult to answer such a question even based on our modern understanding of the term, and the question becomes all the more difficult if we consider that there are no Anglo-Saxons left to ask for their opinion. The goal of this section is not to give an exhaustive definition of Old English wisdom but rather to provide an overview of the different representations and notions of the concept found in Old English literature. Sources for this endeavour include shorter works from the Exeter Book, such as The Wanderer, The Seafarer, as well as the Old English version of Apollonius of Tyre, some texts by and about King Alfred, and Beownlf.

Let us start our discussion of wisdom in Old English literature with lines 6569 from The $W$ anderer, as they give a fairly straightforward idea of what constitutes wisdom for the poet:

Wita sceal gepyldig:

ne [sceal] no to hatheort, ne to hrædwyrde,

ne to wac wiga, ne to wanhydig,

ne to forht, ne to fægen, ne to feohgrife,

ne næfre gielpes to georn, ær he geare cunne. ${ }^{2}$

If interpreted very broadly through a modern lens, one could imagine this to mean that a wise man is someone who is patient and calm and as such someone who is also less likely to lose his temper in times of adversity. One could further imagine him to speak in a reflective and eloquent manner, while never giving up on his endeavours when he wants something. He would never lose his sense of moderation, though, never becoming condescending towards his peers and never falling prey to arrogance either. Yet the context of Anglo-Saxon literature and the poem in particular forces us to look at the passage from a different perspective. One has to take into consideration, for example, that Christianity was a relatively new thing in England and that contemporary literature was strongly marked by the influence of monks, as literacy was far from universal in Anglo-Saxon society. From that

\footnotetext{
2 "A wise man shall be patient: / he shall not be too hot-hearted, not too hasty of speech, / nor too weak a warrior, not too reckless, / nor too timorous nor too eager, nor too greedy for riches / nor ever too desirous of boasting, before he clearly may have knowledge." All quotations and translations from The Wanderer are taken from Treharne's Old and Middle English, c. 890-c. 1450: An Anthology unless otherwise indicated.
} 
perspective, it is relevant that many of the dos and don'ts seem to refer to the virtues and sins that Anglo-Saxons could have found in the Bible and early religious writings. One could for instance relate hatheort ("hot-hearted") to wrath (ira), just as one might see feohgifre ("greedy for riches") as an allusion to greed (avaritia). What is more, some of the words employed by the poet were normally used in a religious context at his time. The word forht is a good example of this as it meant "fearful" and "in awe of God," while the word wanhydig falls into the same category as a word used to refer to men at odds with "the Father in heaven" ("Fæder on heofonum," 115; Dunning and Bliss 36-73). It is aspects of this nature which lead Dunning and Bliss to the affirmation that the wisdom in The Wanderer is "the wisdom of the counsels of the Christian life" (101).

From such a religious perspective, the poet's mention of the wac wiga ("weak warrior") or the boasting ("ne næfre gielpes to georn") seems somewhat out of place in this reading, as these references allude to a more heroic understanding of the world. But the poet's combination of character traits and attitudes can be seen as a unification of a formerly heroic and purely pagan understanding of the world with the advent of Christianity. The Anglo-Saxon period does not allow us to see these worlds in isolation from each other because people continued to ascribe heroic attributes to a God who was in general often depicted "as a warrior, ruling with power" (Coogan 775). One can see this fusion of Christianity and heroism in the account of the crucifixion in The Dream of the Rood (Mitchell and Robinson), for instance. As Langeslag points out, the characteristics and attitudes from lines 6569 of The $W$ anderer are in fact all "tailored for use in a heroic context." Whether more religious or more secular, it would seem, then, that a first description of Anglo-Saxon wisdom is that a wise man is one who is able to fare well as a Christian in a heroic society, finding consolation in the promises of his religion in light of the inevitable transience of his world.

The awareness of this worldly transience is at the heart of the poem and it is necessary for the eardstapa ("earth-stepper," 6) to ruminate on this principle because that is part of the road to wisdom-a wisdom "by meditation" in the words of Dunning and Bliss (84). Hence, it is the verb geondpencan from line 89 that we need to turn our attention to now. Bosworth-Toller gives "to think over," "consider" or "contemplate" as possible translations and Sheppard provides the more literal "to think through or beyond" (131). All of these interpretations have a deep mental investment in common and such a notion of reflection is crucial for our discussion of wisdom. The question now arising is what one would need to reflect upon if one wants to be wise. The immediate context of the poem suggests that such reflections need to revolve around God's divine power and the bitter certainty that all life on earth is lane ("transitory," 108). But the eardstapa is also said to ruminate on his personal experiences, which might represent another building block of Anglo-Saxon wisdom and one that possibly marks a more secular way of understanding The $W$ anderer. 
The relevance of geondpencan, or reflection, becomes all the more interesting if one considers that Anglo-Saxons were a "riddling culture" (Roberts 18). Roberts points out that riddles were seen as a "truer representation of reality" which led Anglo-Saxons to be "more minded than moderns to view life as a puzzle and a mystery" (18-20). The link between riddles and wisdom is relatively easy to construct as the idea of riddles being used in competitions and as tests for wisdom is ancient (Honegger, "Riddle" 90). Such a notion of riddles as a measure for wisdom is also present in the Old English version of Apollonius of Tyre. The plot of this romance revolves around Apollonius reaffirming his identity as a wise man by first solving King Antiochus' riddle and later showcasing his scholarly, more bookish wisdom as a teacher for King Arcestrates' daughter. The motif of wisdom and learning is a very important one in Apollonius of Tyre and the main character Apollonius is said to be snotor ("wise") from his earliest appearance (1. 41). ${ }^{3}$ King Antiochus sets a riddle that every potential future husband of his daughter needs to solve before he can have her hand in marriage. Although King Antiochus does not hold true to his word and beheads every potential husband whether able to solve his riddle or not, we witness the riddle as an obstacle to overcome-and an obstacle, we should note, that requires a thorough mental investment. Apollonius trusts in his wisdom (snotornesse, 1. 42) and his "scholarly learning" (boclicu lar, 1. 43) 4 and rightly thinks he is well prepared to solve the riddle.

The word riddle as such is even etymologically related to reading (Holmes 88) and the link between wisdom, riddles, and books implies that the act of reading alone might have been thought to lead to wisdom in Anglo-Saxon England. People would have ruminated on the contents of particular books far more than modern readers tend to do because books were less numerous and most literate people would either know a particular book very well or not at all. We learn from Alfred's translation of Boethius' De Consolatione Philosophiae that it is gewit ("intelligence," ch. $5,1.32)^{5}$ which gives value to books; hence, books can be seen as a source of wisdom to the extent that people reflect upon what they read. It is such bookish, scholarly wisdom (boclicu snotornesse, 1. 37) that is specifically required to solve King Antiochus' riddle, which Apollonius does "mid wisdom" (1. 55) and consulting a book to make sure. The character passes the test and even though King Antiochus is a fraud, one should keep in mind that the riddle can be seen as a test to find out who is worthy enough to take his daughter as wife and thus marry himself into a courtly position with potential chances of ruling. From such a perspective, the

\footnotetext{
${ }^{3}$ All quotations from Apollonius of Tyre are taken from Treharne's anthology, just like the translations.

${ }^{4}$ The terms lare and snotornesse are used almost synonymously in Apollonius of Tyre, which further highlights the close link between wisdom and learning. Bosworth-Toller also gives "teaching," "instruction," or "lore" as alternative translations for lare (I).

5 All references to the Old English version of The Consolation of Philosophy are by chapter and line number to the B-text in the edition by Godden and Irvine.
} 
riddle can be seen as a test of wisdom and thus of the likelihood of later good governance, the practice and ability of being a good ruler, on which more below.

It is worth having a look at two further aspects from Apollonius of Tyre: the notion that wisdom can be taught and the continuity of wisdom that follows from this belief. When we talk about bookish learning as a prerequisite for wisdom, it is clear that the aspect of teaching must play a role to some extent because nobody is born literate, let alone having read all the books. It is also clear that this introduces a certain dependence on others (a willingness to teach or to lend books, people having written down something worthwhile) and on providence (being born into a situation where books and literacy are accessible). Having said that, the idea of wisdom via books also provides a certain independence, as books can be read by oneself if one is literate and if reading material is available. An author stores his thoughts and insights in the material object of the book, thus making it possible that a later person can read the material and decode its meaning via the use of geondpencan. Apollonius is "well instructed in all things" ("on eallum pingum wel gelæred," 11. 269-70) and his character functions as a lareow ("teacher," 1. 372) in the romance. His relationship to Arcestrate is primarily that between a student and a teacher; the king's daughter is "lare lufigend" ("a lover of learning," 1. 293) and proves to be a committed student spending her time reading and learning while other young men want to court her. This idea of being taught wisdom, or being taught to read, which might be seen as a prerequisite for wisdom, can also be found in the Bible, where Wisdom is personified as a woman in Proverbs 1-9 (Coogan 895). Such a notion is also present in Alfred's version of The Consolation of Pbilosophy, where Wisdom is established as Mind's teacher from the beginning as a sort of fostermodor ("fostermother," ch. 3, 1. 12). When Apollonius and Arcestrate are separated after the shipwreck, the woman becomes herself a lareow, passing her wisdom on to others as a priestess. Apollonius does so too by writing two books about his adventure, placing one of which into a bibliotheca (1. 464) for others to read and reflect upon.

It should be noted that Arcestrate becoming a priestess after the teaching she receives from Apollonius is something that puts the romance's scholarly wisdom into a rather religious light. The thought imposes itself that the bookish learning entailed primarily studying the Bible and other available religious texts. The Bible, one should remember, is in itself a book which requires serious geondpencan on the part of its readers. Christians are supposed to ruminate on the meaning of God's words, which makes Scripture itself a source of wisdom: the text and the complex issues it addresses, such as mortality and the afterlife, require deep reflection in order to be digested. The question is whether the reading of purely secular books can provide the same level of wisdom. This is clearly possible if the act of geondpencan is understood as something leading to wisdom sooner or later regardless of its content or whether there must be a particular awareness at the end of the process of reflection. In my opinion, Old English literature stresses the importance of 
the religious themes subject to reflection, whereas today we might be more tempted to make the secular process of reflection as such responsible for the acquisition of wisdom. In general, we can say that Saint Augustine's definition of wisdom as "the knowledge of things divine" (De trinitate 14.1: Haddan 361) seems fairly accurate for the Anglo-Saxon period as well because the concept of wisdom is associated with Christianity throughout Old English literature. Staying with Apollonius for the moment, we read that he solves King Antiochus' riddle "with God's help" ("mid Godes fultume," 1. 55) as if the solution comes to him via divine inspiration. Such a thought suggests that wisdom is nothing else than God's practical help offered in times of necessity. The Bible often equates wisdom with the fear and acceptance of God and his power as the Creator. People conscious of God's power and the transience of their earthly existence were more likely to be associated with wisdom, because wise decisions, from this perspective, revolve around the need to behave in such a way on earth as to assure entry into heaven once the earthly roads can no longer be trodden.

Moving on to the aspect of wisdom being tested in order to assure good governance, we can say that both passages involving kings in Apollonius of Tyre have this underlying motif. King Antiochus' riddle contest, though a fraud, is ultimately a test of wisdom for those desirous of a position with kingship. Similarly, Apollonius winning Arcestrate's heart is also nothing else than the main character's wisdom being tested to find out about good governance-the king's daughter explicitly states that she loves Apollonius for his wisdom (1. 407). It is clear that these ideas emphasise the requirement of wisdom for anybody wishing to rule.

No analysis of this subject based on Old English material could do without looking at the role of King Alfred. His contemporary biographer Asser, a Welsh clergyman, relates how Alfred bemoaned the fact that some of his subordinates in high positions did not pursue wisdom with as much attention as he would have liked. Following any unjust sentence, he has the king berate his judges in words like the following:

I am astonished at this arrogance of yours, since through God's authority and my own you have enjoyed the office and status of wise men, yet you have neglected the study and application of wisdom. For that reason, I command you either to relinquish immediately the offices of worldly power that you possess, or else to apply yourselves much more attentively to the pursuit of wisdom. (Keynes and Lapidge 110)

What Alfred does is establish a link between the requirement of wisdom and the responsibilities of kingship, or of those people in a position to rule over others on a smaller scale. What Alfred generally understands as wisdom will hopefully become clearer in the following paragraphs, though Ryan suggests that his "emphasis is on practical wisdom and it seems to refer to the king's ability to make society work, and to maintain good order. [He] puts the emphasis on temporal things 
and never on ideals or on the spiritual dimension to the life of mortals" (159). Shippey strikes a similar chord when he says that Alfred's wisdom means "doing [one's] job, building for the future, considering matters (whether secular or spiritual) in the long term" ("Wealth and Wisdom" 354; both his analysis and Ryan's build on Alfred's Preface to the Pastoral Care). We see already that the two scholars introduce a more secular layer in Alfred's understanding of wisdom, arguing for practical applications related to the requirements of good governance.

The general notion of wisdom associated with King Alfred-and wisdom is one of the "most persistent themes" about him in medieval writings (Keynes and Lapidge 47) - is one similarly marked by bookish and scholarly learning as the impression we get in Apollonius of Tyre. In his Preface to the Pastoral Care, Alfred famously laments the state of learning in his realm. Unlike in earlier times, most people were no longer able to read the books that survived in Latin because they were no longer trained to read the language of sophistication and knowledge, and depended on vernacular translations instead. Shippey points out that the wela ("wealth" [i.e. of books], 1. 29) ${ }^{6}$ that Alfred's country possessed was no longer worth anything if people could not take any advantage of it—despite the fact that "[t]he wealth was all around them" ("Wealth and Wisdom" 347). For Alfred, England had been a better place in these former times when people paid more attention to scholarly learning and he speaks of that past in a melancholy way. For England not only saw a decrease in reading and learning but also a decrease in religious fervour which might be explained by the fact that many of the neglected books in that time were religious in nature and many of the literate men were clerics. Alfred's laments epitomise an idea of loss-the loss of the former ability to indulge in Latin learning, and thus in the wisdom from earlier days, all swallowed up by the ever so apparent incapacity of reading the ancient languages.

However, Alfred has also been called "the ultimate scholar king" and this must be due to his reputation as a medieval translator (Irvine 143). As he suggested in his Preface, vernacular translations of the most important books are the ideal solution to the increasing loss of wisdom that he felt in his time. The list of works that he and his collaborators translated, though, is a list of almost exclusively Christian works which was supposed to form the basis for religious improvements (Keynes and Lapidge 23-35). Such a canon implies that the concept of wisdom was inseparable from religious fervour in Alfred's eyes and that the more secular idea argued for above would in fact be nothing more than a direct result of religious devotion, rewarded by God with the ability of good governance. The act of translation itself is of course something which makes a deep and thorough reading of the original necessary and this is in direct relation to the concept of geondpencan. In order to translate, a scribe must decode the foreign language, interpret the exact meaning of the text, think about how he could express the idea in his own language while

${ }^{6}$ All quotations and translations from the Preface are taken from Treharne's anthology. 
constantly thinking about potential deviations in light of his audience. Alfred tells us in his Preface that he himself translated "sometimes word for word, sometimes in a paraphrase" ("hwilum word be worde, hwilum andgit of andgiete," ll. 53-54) which shows that he was not unwilling to take certain liberties in his translations. His Old English version of The Consolation of Philosophy is quite loosely translated from the Latin original - with adaptations aimed at his Anglo-Saxon context making the work more Christian (Godden and Irvine 1: 66-67)_-which implies that Alfred reflected on the work very thoroughly. This aspect of deep reflection on the writings available underlines once again that reading was more associated with reflection in medieval times than it is in our time. Today, many people consume literature without ruminating on what they read, their literary adventures being aimed more at entertainment rather than the attainment of wisdom.

If we look at the construction of Alfred's reputation as a wise man, taking Asser's accounts as a basis, we see that Alfred seemed to be renowned for an unquenchable thirst for knowledge and learning which he had from young age on. According to Asser, it is the "desire for wisdom" and the "nobility of his birth" which characterised the king (Keynes and Lapidge 75). This is an interesting point, as it suggests not only an interest in wisdom as a prerequisite for attaining it but also an aspect of genealogy. This aspect of birth can be understood from two different perspectives. The first one would be that Alfred was lucky to be born into a family which made books and learning accessible to him, while the second one would be that his birth as a future king marks him with a certain kind of divinity, as God's chosen representative on earth to rule over Wessex. Obviously, the first aspect is linked to religion no less than the second, because much of the available literature would have been religious in nature. Moreover, it is a wellknown anecdote that Alfred learned a book by heart while still a child (Keynes and Lapidge 75). The very idea of him being wise as a child suggests that the common association of wisdom with older people, something we will turn to in a moment, did not seem to apply in his case, since he is portrayed as a relatively wise person from the beginning. But such information has to be taken with care, because Asser later reveals that he did not personally know Alfred before the latter was an adult, meaning that Asser himself has to rely on hearsay (93). Neither should it be forgotten that Alfred was the King of Wessex and that people should be expected to be deferential to the king and to speak well of him, especially if they are personally known to the king and write a biography about him. We should therefore consider that Alfred's wisdom might have been something external to him as an individual, rather pertaining to his position as a king. After all, kings were believed to rule by divine will, which makes their association with wisdom only too understandable. One should also take into account that Asser was writing with the purpose to present Alfred as a good and just ruler to Welsh monks and that his approach thus cannot have been altogether objective (Keynes and Lapidge 56). This is also why Alfred is presented in a very Christian light, as a 
biblically learned man, having visited the Pope in Rome, even being compared to Solomon (ch. 8, 76). The idea of his wisdom at a young age can also be seen as Asser's attempt to present a more straightforward picture of Alfred's road to kingship and wisdom in retrospect. After all, the king was a "literary construction" in his own time already (Keynes 14) and his close link to wisdom led later people to name a collection of proverbs after him, assuming they must have derived from him (Keynes and Lapidge 47).

The contemporary and later veneration for King Alfred might or might not be due to his wisdom. It is questionable whether he would have enjoyed the same reputation if he had not saved Wessex from the numerous Viking attacks in his lifetime. It is likely, then, that the ascription of wisdom to Alfred is closely tied to the king's success on the battlefield, when he served and protected his (future) kingdom. As Asser describes it, wisdom served him well on the battlefield, receiving "divine help" in moments of great need (79). This makes it only symbolical that he fights on the Christian side against the Viking pagans, which almost makes him seem like a Messiah. Perhaps Asser renders the accounts more religious than a less devout person would have done, but both Alfred's wisdom and his heroic achievements on the battlefield are linked to religion. It has already been mentioned that wisdom is a prerequisite for good governance, but Alfred is also established as a rightful king via his success in battle. "[L]uck in battle" was considered to prove divine justification of kingship according to early Germanic beliefs before the Christianisation of England (Ford and Reid 71-73). It is clear that such an emphasis on battles becomes all the more important if we consider the heroic past of Anglo-Saxon England. Alfred conforms to the twin prerequisites of good governance, wisdom and heroism (here as success in battle), ${ }^{7}$ and this makes it all the clearer why he lamented the decrease of both wig ("warfare") and wisdom (1. 7) in his Preface-because only such a combined presence of the two could usher in new times of glory. As Asser shows, it is his unification of both wisdom and a general aptitude in battle which made his early rise to power possible. Alfred preceded his older brothers because he surpassed them "both in wisdom and in all good habits; and in particular because he was a great warrior and victorious in virtually all battles" (80-81). Hence, King Alfred combined, at least according to Asser, both the religious, even Christian element of wisdom-described in his version of the Consolation as "the highest virtue" ("hehsta cræft," ch. 27, 1. 47)— and the heroic element of warfare.

Such twin prerequisites of good governance can also be found in Beownlf, where kings like Hrothgar and Beowulf are consistently associated with both wisdom and heroism. The notion of good governance in Beownlf will be discussed at greater length in the section on heroification of the wise below and shall not

\footnotetext{
${ }^{7}$ Although there are and were certainly other characteristics of good rulers, the scope of this paper obliges me to focus exclusively on wisdom and heroism as the most basic and most important requirements of good governance.
} 
preoccupy us for the moment. Instead we will now turn to another notion connected to the concept of wisdom. A look at Hrothgar, the "snottra fengel" ("wisest of princes," Heaney, 1475), ${ }^{8}$ suggests that wisdom is related to old age. For example, we learn that he is "in the wisdom of [his] winters" ("wintrum frod," 1724), the idea being that the passing of time alone brought him wisdom. This aspect can also be found in The $W$ anderer, where nobody is able to become wise before having his "share of winters" ("Forbon ne mæg wearban wis wer ær he age / wintra dæl in woruldrice," 64-65). Such a link between wisdom and old age might be explained by a general human veneration for older things although one could also imagine a link to the idea of geondpencan again. Maxims II teaches us that "an old man knows most things, a man made wise by distant years, who has experienced a great deal before." 9 This notion of older people being wiser because of their wider experience suggests that these people also ruminate on their experiences and are able to apply lessons learned to their current situation. If an idea of applicability is behind the experiences, this also means that experiences as such are not worth much, as they first need to be reflected on actively in order to provide wisdom and practical help. If this were not the case, every old man or woman could be considered wise just because of his or her time already lived. It certainly needs explanation why Beowulf and Wiglaf are described as wise even though their age is not yet far advanced. ${ }^{10}$ It is possible that their experiences are the reason for their apparent wisdom; both Beowulf and Wiglaf are experienced warriors despite their age, which means that they have seen more bloodshed and suffering than normal Anglo-Saxons would have experienced. This makes them more likely to think about the meaning of the suffering, of life as such and what might happen to the people left slaughtered on the battlefields. It is Christianity which offers an answer to the above and it is not age, then, which determines a person's wisdom, but the "spirit in a mortal, the breath of the Almighty" (Job 32:8)11 and ultimately whether the person believes in God or not. Old people were and are naturally closer to their own death and hence more likely to reflect upon issues like mortality and worldly transience. From that perspective, young people might also be considered wise if they ruminated on the same issues. However, it might be of more help to frame such an explanation of young people being wise more directly in the heroic context of Anglo-Saxon England and its literature. Both Beowulf and Wiglaf might simply be called wise because of their heroic spirit as demonstrated in the poem. Their wisdom might be grounded in their obvious ability to get by and even excel in a heroic society.

\footnotetext{
8 All quotations from Beownlf follow Liuzza's second facing page edition (2013), with omission of all macrons. Translations are generally also Liuzza's, except when marked as Heaney's.

9 "[A]nd gomol snoterost, / fyrngearum frod, se pe ær feala gebideð" (11-12, my emphasis). All quotations from Maxims II, and later also from Maxims I, follow the edition and translation in Shippey's Poems of Wisdom and Learning.

10 The same may be said of King Alfred and Apollonius.

11 All biblical quotations follow Coogan's edition of the New Revised Standard Version.
} 
If we look at Hrothgar's sermon now, we realise that this is in essence a description of an old man explaining worldly transience to a younger man in the blossom of his strength. The motif of the old teaching the young is ancient and also figures in the Bible, for example when the student of wisdom is described as a child listening to his parents (Prov. 1:8-9). In lines 1761-68, the old and wise Hrothgar instructs the protector of his realm:

$\mathrm{Nu}$ is pines mægnes blæd, ane hwile; eft sona bið, pæt pec adl oððe ecg, eafopes getwæfeð, oððe fyres feng, oððe flodes wylm, oððe gripe meces, oððe gares fliht, oððe atol yldo; oððe eagena bearhtm forsiteð ond forsworceð; semninga bið, pæt ðec, drythtguma, deað oferswyðeð. ${ }^{12}$

As Hrothgar explains, death is inevitable and the old know this by personal experience because they have witnessed themselves the way old age sips away the strength and agility of youth. I want to draw attention to the heroic manner of Hrothgar's description of death: words like ecg ("sword"), eafo ("strength") and gar ("spear") mark this passage about death and it almost seems as if the wise old king describes death as a lost battle that was fought heroically until the end, with death as the logical culmination of all his earthly battles. This means there is a close connection between the awareness of mortality and the heroic nature of the poem. Christianity brought the hope of an afterlife to Anglo-Saxon England (CrossleyHolland xvi), to all those who behaved according to biblical maxims, which means that death is no longer final but only something which "split[s] asunder / ... life and ... body" ("sundur gedælan / lif wið lice," 2422-23), because the soul would ascend to heaven. This means that people no longer needed to fear death theologically and such an absence of fear might be especially useful for heroic warriors, who constantly had to risk their lives. ${ }^{13}$ Hence, Christianity comes in handy for the old heroic spirit and it is even wise for the hero to cling to the new religion because it gives him all the more strength to pursue his heroic endeavours, knowing that he will only step onto the next road if he were to die. Death under such heroic circumstances as Beowulf's own death after his fight with the dragon represents a wundordeað ("wondrous death," 3037) and Beowulf tells us he is "ready to be slain" (walfus 2420, trans. Bosworth-Toller) and to part on his next adventure.

\footnotetext{
12 "The glory of your might / is but a little while; too soon it will be / that sickness or the sword will shatter your strength, / or the grip of fire, or the surging flood, / or the cut of a sword, or the flight of a spear, / or terrible old age_-or the light of your eyes / will fail and flicker out; in one fell swoop / death, o warrior, will overwhelm you."

13 Prior religious belief came without promises of heaven. See also the discussion of Ragnarök under "Heroification of the Wise and Demystification of the Heroic" below.
} 
Hrothgar describes life as a heroic battle which can only be lost in the end, though the manner of it is decisive. It is such an awareness of worldly transience, then, which seems to represent the wisdom in Beownlf and so many other Old English texts. It should be noted that young people like Wiglaf or Beowulf in the first part of the poem can also be called wise as they frequently see people lose the battle against death on the battlefield. The awareness of mortality is very close to them. And it is indeed such veterans to whom the poem typically ascribes wisdom, especially if we take into consideration that many of the people surrounding the king would have probably had some battle experience as well. It is thus the heroic fighters who are wise and it is their wisdom, their trust in an afterlife, which reinforces their courage in battle, with their religious faith thus refuelling their heroic conduct.

The aspect of worldly transience is found throughout the corpus of Old English literature and is far from being unique to Beownulf. It is commonly agreed that the notion of loss and death encapsulates the main theme of Old English literature as a whole. Coming back to The $W$ anderer, we can say that it is this aspect of mortality which forms the basis of a wise man's awareness. The poet concludes:

Eall is earfoðlic eorpan rice;

onwendeð wyrda gesceaft weoruld under heofonum.

Her bið feoh læne; her bið freond læne;

her bið mon læne; her bið mæg læne.

Eal pis eorpan gesteal idel weorpeð. $(106-10)^{14}$

The Wanderer emphasises the worldly transience from its beginning with the lonely eardstapa until the end of the poem. The word lane as such can be found throughout Old English literature and this high frequency of use also suggests, on a lexical level, that the theme of loss and death was an omnipresent one. ${ }^{15}$ All this earthly struggle can lead to the assumption that real wisdom is shown only by him who concludes, like the speaker in The Seafarer, that "the joys of the Lord are / warmer to me than this dead life, / transitory on land. I do not believe / that earthly happiness will endure eternally." 16 All those not believing in God are foolish, whereas "the man who lives humbly [is blessed and] the favour of heaven will come to him." ${ }^{17}$ It is this notion of eapmod which is decisive and Bosworth-Toller gives "lowly," "submissive" (Supplement sense i) or "obedient" (original entry)

\footnotetext{
14 "All is hardship in the earthly kingdom; / the action of fate changes the world under the heavens. / Here, wealth is transitory; here a friend is transitory; / here a man is transitory; here a kinsman is transitory. / All this earth's foundation will become empty."

15 The word appears throughout the Old English texts subject to my analysis and its numerous occurrences referred to in Bosworth-Toller further cement this impression.

16 "Forpon me hatran sind / Dryhtnes dreamas ponne pis deade lif, / læne on londe. Ic gelyfe no / pæt him eorðwelan ece stondeð," 64-67. All quotations and translations from The Seafarer follow Treharne.

17 "Eadig bið se pe eapmod leofap: cymeð him seo ar of heofonum," 107.
} 
along with Treharne's choice of "humbly." This seems to be a man's road to the afterlife, via the awareness of God's power and his willing subordination to it. Therefore, it is wise "to look after [one's] soul" ("snotre men sawlum beorgað," Maxims I 36) because it is the part of humans that will go to heaven, the soul being, as we learn in Alfred's Consolation or the Bible, eternal ("undeaplice and ece," ch. 11, 1. 84). In Beowulf, the ignorance of worldly transience is called unsnyttru ("folly," 1734), the opposite of wisdom, which means by implication that wisdom entails an awareness of worldly transience. Such a representation of life on earth as transitory, hard, and ending in death is a representation that borders on fatalism and yet also gives birth to the consolations of the afterlife offered by the Christian religion. However, it seems to be this respectively fatalistic or promising aspect of life, death, which is at the core of the geondpencan in The Wanderer, the faithful reflections leading onto the road to Anglo-Saxon wisdom.

Drawing our overview together, we can say that the notion of wisdom in Old English literature fuses the Christian present of the Anglo-Saxons with their heroic heritage, giving the idea that wise people are those who are able to cope well as Christians in a heroic world. The fact that many scribes had a religious background certainly biases the findings and it would seem that wise decisions are primarily those that are made with existence after death in the back of the mind. However, this does not mean that the Anglo-Saxons acknowledged no other way to wisdom than the biblical path. Reading, experience, and reflection, three of the most common associations of wisdom in the Old English literature I analysed here, are just as important prerequisites from a purely secular perspective, as I hope this section has shown. Even in our modern times, where the commitment to the Church is more and more declining, we might be tempted to think of these three prerequisites as the cornerstones of any road to wisdom.

\section{Tolkien's Road: The Importance of Wisdom in The Lord of the Rings}

The Oxford English Dictionary defines wisdom as the "[c]apacity of judging rightly in matters relating to life and conduct" or a "soundness of judgement in the choice of means and ends" (1a), and it is primarily through such a lens of decisions that we will approach the concept in The Lord of the Rings. We will briefly examine the general influence and importance of wisdom in Tolkien's magnum opus, especially as far as the execution of the quest is concerned. The most promising way of doing this is by looking at Elrond's Council, the strategic core of the novel, where the wise are gathered to decide what to do with the Ring. 
To start with, the Council of Elrond scene is an important moment for the plot as it describes how an assembly of the wisest minds in Middle-earth ${ }^{18}$ discusses what to do about the Ring. The Council's decision is based on the reflection, the geondpencan, of the people present, over the facts established during the meeting. The conclusion is that the Ring needs to be destroyed at the Cracks of Doom, a fellowship is sent out on that errand and the story ends, some 800 pages later, with the successful destruction of the Ring and the victory over Sauron. One might feel tempted to say that the plans of the wise people from the Council bear fruits and that the final victory is a direct consequence of the meeting's decision. Such a conclusion would be too simplistic, though, as Tolkien's novel continuously gives the impression that the quest's success depends on chance and luck at various critical moments. As Gandalf points out, "there was something else at work, beyond any design of the Ring-maker" (56), thus alluding to a higher power ruling over the protagonists. It is called "chance" that the hobbits have the Ring and both Bilbo and Frodo are supposedly "meant" to bear it $(51,56)$. One could even argue that Frodo's decision to carry the Ring to Mordor himself is prompted by the fact that the Ring came to him, chose him as its bearer and burdened him with the task, making Frodo's decision seem to hinge on his fate more than on his own desires. This shows, then, that there is a constant interplay of fate and free will at the heart of the quest. ${ }^{19}$

It is therefore necessary to look at such an overarching power if we want to assess the importance of wisdom for the quest's success. "Gæð a wyrd swa hio scel," Beowulf tells us ("fate always goes as it must," 455), and the wise characters in Middle-earth also seem to be aware of a higher power to which they are subject. Consequently, it is the mark of wisdom to know that one does not necessarily understand all the purposes of such a power, as Gandalf teaches Frodo when the hobbit presumes the right to judge the death of Gollum deserved:

Deserves it! I daresay he does. Many that live deserve death. And some that die deserve life. Can you give it to them? Then do not be too eager to deal out death in judgment. For even the very wise cannot see all ends. (59)

\footnotetext{
18 Interestingly, some of the wisest people, such as Celeborn, Galadriel or Faramir, are not at the Council. One could imagine these characters and their wisdom and counsel to be landmarks in the quest. Concerning the question of which characters I consider to be wise in my paper, I follow Dickerson's experiment which shows that Gandalf, Aragorn, Faramir, Elrond and Galadriel are the characters most commonly associated with wisdom by readers of The Lord of the Rings (48). My research about wisdom will revolve around the requirements of the quest, however, which means that I will also take different characters into account.

${ }^{19}$ For the sake of brevity, I will not differentiate between the different layers of meaning implied by fate, providence, wyrd, chance, luck, divine will or other similar notions in this section. There is much to explore in terms of Tolkien's use of fate and providence in relation to Germanic or classical ideas, as done for example by Dubs. For our current purposes, however, it suffices to say that there is an interplay of what the characters can do and achieve by their own volition and in how far they are controlled by a higher, external source of power.
} 
The hobbit cannot know what providence has preordained for Gollum; indeed, in a dramatic resolution, Gollum, "the instrument of divine providence" (Hibbs 170), will inadvertently complete the task once Frodo gives in to the lure of the Ring. This shows that the Council's plan would not have been successful if the higher power had not done its share. The Council's decision to take the Ring to Mordor emphasises agency on the Fellowship's part, though in the end, it is the unforeseen developments which turn their fate around, making Frodo not an active hero but a passive bystander at the critical moment.

All this suggests that the protagonists are not in control of the outcome of the quest and this might even lead to the assumption that all decisions, no matter how wise, are ultimately vain because the higher power always has the final word. Yet such a conclusion could not be further from the truth, as Shippey explains:

[T] he logic of luck (or chance, or fate, or fortune, or accident, or even wyrd) seems in Tolkien's view to be this: there is no knowing how events will turn out, and it is certainly never a good idea for anyone to give up trying, whether out of despair or out of a passive confidence that some external power will intervene. If there is an external power (the Valar), it has to work through human or earthly agents, and if those agents give up, then the purpose of the external power will be thwarted. ( $A u$ thor 146)

The conscious decision for agency, brave and heroic in nature, is thus an important prerequisite for the quest's success, and it is this decision which embodies Tolkien's notion of wisdom as far as the quest is concerned. Frodo accepts his fate and displays the necessary agency, which brings the higher power to work and leads to the "eucatastrophic" (Tolkien, "On Fairy-Stories" 153) situation where Gollum can stumble together with the Ring into the Cracks of Doom. "[I]t is wisdom to recognize necessity," Gandalf proclaims at the Council of Elrond (269), and even though many of the subsequent decisions following the Council seem more careless than wise-even without real alternatives such as trusting in Gollum - it is important to note that these decisions are still made with the required responsibility and agency in mind. They are in accordance with the final goal established by the wise in Rivendell. The characters go "ever on and on," just like in Bilbo's walking song (35), for dismissing their responsibility is unthinkable as it will only leave the problem for another generation with even worse chances of success, as both Elrond and Gandalf explain (279, 879). Staying passive is neither wise nor heroic and that makes agency necessary, even if walking out of one's door is "a dangerous business," as Bilbo tells us, and "there is no knowing where [one] might be swept off to" along the road (74). It is obvious that the initial decision of the wise people gathered at Elrond's Council is at the heart of the later victory, even though the characters' courage and persistence, coupled with the sudden positive turns issued by fate and providence, are of greater importance once they are on their way. 
The following three sections will examine representations of wisdom in The Lord of the Rings directly related to Tolkien's philological background. While I will make occasional reference to other texts from Anglo-Saxon England discussed in the overview section, the main focus of my Old English analogies will be on Beownlf. The link between wisdom and religion, however, will only be of marginal interest to us even though there is a great deal to explore in that direction, ${ }^{20}$ given that Tolkien was a devout Catholic and that Christianity figures prominently among Old English associations of wisdom. The next section will examine philology as a source of wisdom, by looking at songs and stories and the way they relate to what I call the circularity of fiction. The subsequent section will analyse the role of information and counsel as the currencies of wisdom, which are sought and traded like the gold in Beowulf. The final section will present some more elaborate thoughts on the interplay of wisdom and heroism in The Lord of the Rings and Beowulf.

\section{Ancient Wisdom and the Circularity of Fiction}

Let us now turn to songs and stories in The Lord of the Rings in order better to understand how Tolkien emphasises the importance of ancient texts and philology. These metafictional entities have the power to bring the examples and wisdom of earlier people into the minds of the characters and they can encourage characters in key moments of the quest. Many of the instances when the characters show their own poetic skill are examples of characters fictionalising reality for the benefit of later audiences, real or imagined. "Legend and History have met and fused," Tolkien proclaimed in "On Fairy-Stories" (156), and such a blurred line between fiction and reality can also be seen in The Lord of the Rings, where legends turn out to be true and events from the plot are reworked into fiction by the characters. It will be interesting, then, to contrast the songs and stories in The Lord of the Rings with the metafictional moments in Beownlf. While real and reality are understood as terms designating things that are considered normal in Middle-earth, my notion of fiction refers both to the imagined and to that which is deemed impossible in Tolkien's world. Reality and fiction are merging concepts in The Lord of the Rings and this is why my use of the term fictionalisation also comprises putting events into supposedly factual accounts. If Tolkien's portrayal of songs and stories is linked more with reflection and wisdom, as a potential basis for good decisions, the metafictional moments in Beownlf seem to only put more stress on the heroic quality of the hero.

The fact that history and legend, or reality and fiction, are not clearly separable was very clear to Tolkien as a scholar of Anglo-Saxon. Because of his professional

\footnotetext{
${ }^{20}$ See for example Kerry and Miesel's collection of articles Light beyond all Shadow: Religious Experience in Tolkien's Work for further information.
} 
background, he knew that "legend often became a matter of everyday," as Shippey put it (Road 34). The poem Beowulf makes this quite clear. It relates the fictional story about Beowulf and his struggles against the monsters but the poet obviously draws on reality because there are characters like Hygelac who were apparently historical. This is quite logical because, as Tolkien points out in his essay "On Fairy-Stories," there are always elements from the real, the "primary world," in the fictionally created "secondary" one (113). Even a look at the etymology of the term history shows that earlier generations did not seem to differentiate too much between factual history and fictional narratives, as the word bistory could refer to both things (Onions). According to his friend C. S. Lewis, the author of The Chronicles of Namia, one of the things Tolkien wanted most with his literature was to show the world that "the real life of men is of that mythical and heroic quality" to be found in these ancient tales (15-16). And I think it is clear that, for Tolkien, his mythology and real life fused and there are instances in his Letters where the author tries to make sense of reality by way of his fiction. In a letter to his son Christopher, for example, who was fighting in South Africa during World War II at the time, Tolkien Senior tried to encourage his son by telling him to keep up his "hobbitry in heart" and to think "that all stories feel like that when you are in them," going on to assure him that he is "inside a very great story" (78). By doing that, he gives encouragement to his son, by making him feel part of a fictional narrative, equal to reality, just like his Lord of the Rings, where hobbits may "shape the fortunes of all" (Jackson, Gefährten 00:07:12). Thus Tolkien ascribes a fictional character to reality and treats it like fiction by putting it on the same level. In the end, myths are taken from the real world, as Lewis points out, and by virtue of such myths, we can better understand reality. The line between the two is more blurred than modernity realises. In The Lord of the Rings, there is no clear separation between factual history and legend either. Many of the preliminary pieces of information concerning the Ring are no more than philological remains researched by Gandalf in the libraries of Gondor. Lore and story are therefore two concepts that are barely differentiated in Tolkien's work.

Stories and songs can in general only work as a source of practical wisdom if the people who hear or read them reflect upon them and look for their applicability for their own lives and situations. The link between songs and stories and the importance of reflection is alluded to several times in The Lord of the Rings. For one thing, hearing stories is described as something that does not happen effortlessly (131) and the clear association of Rivendell with both songs and reflection is quite telling as well. The House of Elrond represents "Lore" and the "ancient wisdom" as Tolkien describes it himself, going on to say that it is a place of "reflection" rather than "action" (Letters 153). Stories and songs inspire the characters to reflection in Tolkien's novel, just as his novel might do for its readers, and the reflection is something that transfers the fictional to the real, by applying that which the characters hear in tales with their own immediate situation. Shippey points out for 
example that "the 'Road' poem" appears three times in The Lord of the Rings and that it is each time adapted to the immediate situation of the character reciting it (Author 190). It is hence not much surprising that the wise characters in Tolkien's work are associated with a knowledge of songs and stories and consider the possibility of fiction being real. Bilbo speaks of an unbelievable "appetite for music and poetry and tales" that all the Elves have, for instance, and Aragorn, who is himself firmly rooted in this tradition, tells us that Elrond knows stories best, and this one is the "master of wisdom" after all (237, 191, 1034; App. A). These stories and songs can provide access to the ancient wisdom of former days, and as Gandalf says, there is "a chapter of ancient history which it might be good to recall; for there was sorrow then too, and gathering dark, but great valour, and great deeds that were not wholly vain" (52). Whether the characters reflect upon such things knowing they are factual or not is beside the point; it might provide them with guidance in their current situation in either case. Such metafictional examples where characters tell stories, recite songs or delve into history represent moments where "they bring the wisdom of ancient folk into present" (Holmes 88). These characters are aware of "the shaping of present by past" (Shippey, Road 33) and be that past "true or feigned" (LotR xxiv), it can be of service either way.

There are, however, also characters who do not accept the reality of fiction as a possibility and also refuse the idea that stories and songs can provide ancient wisdom. In "On Fairy-Stories," Tolkien lamented the fact that many people regarded fairy-stories as children's literature and as something that adults should not take too seriously. But as Shippey points out, there is a form of wisdom in the hobbits because they do not downgrade old tradition to children's tales and children's stories; for the hobbits, that remains an "unforgotten wisdom" (Author 26-27). Boromir is more sceptical in that regard, for example when asked about the potential existence of Fangorn: "Indeed we have heard of Fangorn in Minas Tirith ... But what I have heard seems to me for the most part old wives' tales, such as we tell to our children" (374). Celeborn, "the wisest of the Elves of Middle-earth" (357), promptly replies: "But do not despise the lore that has come down from distant years; for oft it may chance that old wives keep in memory word of things that once were needful for the wise to know" (374), thus explaining to Boromir that stories might contain practical knowledge whether they be true or imagined and therefore, wise people do not reject them for their fictionality, or for the possibility that they might merely be imagined. Celeborn understands that being wise and serving as a counsellor is not possible without acknowledging the fact that all his assessments of future outcomes are in his imagination and therefore per definition not real. And those people that see stories or songs as potentially real, or at least as something that might be educational, will be able to apply that wisdom and perform acts in the process that might themselves be worthy to be put into song. Fictional stories and songs can serve as a basis for counsel, like Isildur's written legacy does for the great Council in Rivendell, but stories 
and songs can also function as counsel as such — as the words of Malbeth the Seer do when they remind Aragorn of the Paths of the Dead (781). Stories and songs can only provide that, however, as long as the characters do not reject them too eagerly. Boromir, if we stay with this character, also does not believe in, or understand, the implications of Isildur's example who also tries to use the Ring but fails in the process; showing that it is indeed important to consider legend, or history, or whatever it actually is. Children, Gandalf implies, can do better than many grown-ups because they value fairies differently, as the wizard's discussion about Ents with Théoden shows:

'They are the shepherds of the trees,' answered Gandalf. 'Is it so long since you listened to tales by the fireside? There are children in your land who, out of the twisted threads of story, could pick the answer to your question. You have seen Ents, O King, Ents out of Fangorn Forest, which in your tongue you call the Entwood. Did you think that the name was given only in idle fancy? Nay, Théoden, it is otherwise: to them you are but the passing tale; all the years from Eorl the Young to Théoden the Old are of little count to them; and all the deeds of your house but a small matter.'

The king was silent. 'Ents!' he said at length. 'Out of the shadows of legend I begin to understand the marvel of the trees, I think. I have lived to see strange days. Long we have tended our beasts and our fields, built our houses, wrought our tools, or ridden away to help in the wars of Minas Tirith. And that we called the life of Men, the way of the world. We cared little for what lay beyond the borders of our land. Songs we have that tell of these things, but we are forgetting them, teaching them only to children, as a careless custom. And now the songs have come down among us out of strange places, and walk visible under the Sun.' (549-50)

If the King of Rohan had not dismissed songs and stories as mere fiction created for the entertainment of children, he would have known what overpowered Saruman and now "walk[s] visible under the Sun." Those who are wise know well that fiction merges with the real, that legend might turn out to be true, and they understand that a knowledge of old songs and stories might give them access to the ancient wisdom potentially vital for the quest. ${ }^{21}$ Given the situation of philology in universities in Tolkien's time, his use of stories and songs as purveyors of wisdom can be regarded as a call for philology, an attempt to reaffirm those who are interested in texts like Beowulf.

\footnotetext{
${ }^{21}$ Having said that, I should point out that a knowledge of songs and stories is of course not exclusive to wise characters in The Lord of the Rings. Hobbits, as we learn, are also a singing culture yet not considered to be very wise. The difference might be that wise characters try to learn from songs and stories and let themselves, to some extent, be guided by them along their journey. It might also be worth noting that, unlike Bilbo's songs that are inspired by the Elves and his adventures, the songs in the Shire might not be such a good source of wisdom as they are merely for feasting and do not provoke serious contemplation.
} 
In the Old English poem, there is a different relationship between the metafictional moments and wisdom. We have a different yet similar portrayal of songs and stories with regard to wisdom in Beowulf. The characters can still think about them and learn from them, as in The Lord of the Rings, but the legends behind the legend rather serve to reemphasise Beowulf's heroism, though, and we are never explicitly told that the characters take a breath and actually reflect about the poems inside the poem and try to apply them to their own situations. We have to infer such information from later dialogues or the characters' subsequent actions and the immediate context of these digressions - we will focus on the Sigemund and Finnsburh episodes (867-915, 1063-159) — is one of feasting and the celebration of Beowulf's heroic victories. The poet does not mention that Beowulf stops and reflects on the meaning of the poems, nor does he tell us explicitly that Beowulf tries to apply these legends to his own life. The atmosphere during the scops' contributions is one of celebration, drinking and entertainment and not one of thoughtful reflection like the one in Rivendell. If we look at line 2109, when Beowulf relates his experiences with the Danes to Hygelac, he refers to the scops' tales as "strange stories" ("syllic spell”), "true and sad" ("soð ond sarlic"), which means that the hero must at least have listened to the scops and his assessment of their contributions also suggests that he has thought about them to some extent. How deeply, though, remains speculative. It is Hrothgar, the wise old king, who picks up the Heremod analogy of the Sigemund episode in order to warn Beowulf of stepping into Heremod's footprints; Beowulf should learn from Heremod ("Đu pe lær be pon," 1722) and beware of following the road that the latter lays out. These metafictional moments might have been intended for the listeners of the Beowulf-poem rather than for the characters inside of it, giving listeners the possibility to think about moral and virtuous implications of the hero's actions by comparing the plot of the poem with other well-known legends. The digressions serve to foreshadow future events, such as the later fight against the dragon for example (886), but neither do they provide any direct and tangible wisdom for the main character nor can we link decisions back to Beowulf's reflections about these digressions. However, they provide ancient or imaginative examples, the reflection on which can reignite past guidelines for present situations. The world of Beowulf is a story culture and we can assume that references to Sigemund were understood by the fictional characters as well as by actual Anglo-Saxons in a medieval audience. But Beowulf himself does not need these poems as much as the characters in The Lord of the Rings need them. He is a hero, described as God-sent with all his extraordinary powers, and he does not decide to become a hero only after being inspired by the scops. He is already a hero and therefore, the poetic contributions do not fulfil any function of encouragement-Beowulf already has courage and he does not need further inspiration to fulfil his quests. The Sigemund and Finnsburh episodes do provide a moral warning, but Beowulf either does not realise it or does not follow the counsel of legend. Instead, the scops' performances are linked 
more with Beowulfs heroism rather than with wisdom. Bonjour remarks for example that the Sigemund and Heremod digressions are "a glorification of the hero by means of parallels and significant contrasts" (74) and this could not be more true as the episodes reinforce the level of heroism demonstrated by Beowulf. The two episodes rather suggest that Beowulf himself is of that same heroic calibre and will be put into legend, his heroic achievements fictionalised like the ones of his famous predecessors. The episodes emphasise heroism rather than inspiring reflection in the characters and make us understand that Beowulf himself will one day be remembered among such heroes, as befits his well-earned status. Unlike in Tolkien, none of the characters needs any reminder that legend can become a reality because the world of Beowulf knows quite well that heroes such as the main character of the poem exist - the reality of fiction is accepted in the poem and Beowulf's heroic deeds represent the realisation of fiction; another hero steps out of legend into the spotlight. Wise people in Beowulf are not necessarily associated with songs or stories other than the ones they themselves inspire by their heroic deeds. Other than in The Lord of the Rings, then, the aspect of the fictionalisation of reality, of putting into future legend what is achieved in the here and now, is more present than the aspect of using songs and stories as sources of ancient wisdom.

A brief look at Apollonius of Tyre might also be worthwhile. Even though the romance does not have any comparable metafictional moments, it presents bookish learning as an important milestone on the road to wisdom. The characters inside the Old English Apollonius do seem to obtain much of the ancient wisdom via books, but the impression is that it is primarily the riddle as such which inspires true and deep reflection rather than the content of the books. From that perspective, the main character uses the books only as a way to a solution, a support for the geondpencan process initiated by King Antiochus' riddle. In Tolkien, the songs and stories generally lead to geondpencan, and characters like Sam only find out along the way that they are applicable to the quest. What is more, Apollonius does not have any comparable quest to fulfil. Accordingly, the romance does not show how Apollonius tries to apply what he has learned from books for any personal mission. A notable difference between Apollonius and the majority of Old English literature is that the former has a pagan setting, implying that its protagonist's readings are not biblical. Other characters in Anglo-Saxon literature may find guidance for their earthly decisions in the Bible's many stories and characters. As we learn in the Old English Consolation of Philosophy, "books are full of the examples" of earlier men ("Hu ne wast pu pætte ealle bec sint fulle para bisna para monna pe ær us wæran?" ch. 29, 1l. 11-12), which shows that the guidance and applicability people receive from the past can also mean nothing more than learning from other people's experiences, and without these experiences having already been interpreted by others. ${ }^{22}$

22 The Old English Consolation is quite interesting in that regard. Wisdom (the character) often passes his teachings on in song and often makes use of small analogies to history. This suggests that the 
Coming back to Tolkien, we can say that The Lord of the Rings shows that mere words as such are portrayed in such a way as to have power over reality. This is not especially surprising given Tolkien's philological background. We see this for example with Tom Bombadil who can sing Old Man Willow into obedience or with the little verse he teaches Frodo and the others to call him if the need arises $(120,134)$. This is an interesting point, as it gives the impression that words can bring reality into being, conjuring people and things up from mere imagination. The moment when Gandalf tells Saruman that his staff is broken and it breaks in that very instant is another forceful illustration of the power of words (583). Such a power in songs can also be seen when Sam saves Frodo from the Tower of Cirith Ungol: the hobbit sings "old childish tunes out of the Shire" and gains some "new strength" because of it (908). This shows that songs can also have an encouraging function, the lines bringing back thoughts about home and the reason for fighting on in the first place. In general, songs and stories can either function as a way of tapping into ancient wisdom, of finding inspiration in the stories and examples of others, or as a way of reworking one's own experiences into fiction. The Ride of the Rohirrim into The Battle of the Pelennor Fields might serve as a last example of this. We learn that "all the host of Rohan burst into song, and [that] they sang as they slew, for the joy of battle was on them, and the sound of their singing that was fair and terrible came even to the City" (838). Songs and stories are like fictional entities inherently bound up with reality. ${ }^{23}$ While the Rohirrim sing, the battle "is poeticized and perceived from the aesthetic distance of a future generation" (Eilmann 102). When they sing, they immediately bring the action into fiction again, perhaps retold by a fireside at a later time.

The examples of myth becoming reality are so abundant in The Lord of the Rings that a brief selection must suffice for our purposes. The actual existence of hobbits or Ents, though deemed the stuff of fairy-tales before, is just one case out of many interspersed throughout Tolkien's work. Let us first look at Aragorn's return to the throne of Gondor, an example for the realisation of fiction, for the fulfilment of a legend. ${ }^{24}$ As the last descendant of Isildur, Aragorn is the lost heir to the old Kings of Gondor and much of the plot revolves around him taking over this responsibility by stepping more and more into the role ordained for him by legend. Aragorn proves to be the great healer that was prophesised for Gondor and the sword that Isildur used to cut off the Ring from Sauron's hand is reforged, as legend announced it, making Háma, the doorward of Meduseld, proclaim in astonishment: "It seems that you are come on the wings of song out of

mere musicality in communication might play a role itself and that history might teach as a good or bad example.

23 The March of the Ents is similar in that regard. Pippin relates his impression of the moment: "But I thought it was only marching music and no more, just a song-until I got here, I know better now," showing the power behind the song (565).

24 This marks the prophetic nature of the poem in Gandalf's letter to Frodo quoted at the beginning of the introduction. 
the forgotten days" (511). Aragorn is an embodiment of legend and therefore illustrates with his very person that the old days should never be forgotten as they might still hold very tangible implications for the present. We see here that myth and legend, the fictional, have even a kind of prophetic side to them in The Lord of the Rings — in the end, Aragorn does get to step into the role ordained by legend and is crowned in an old traditional ceremony that gives life to the past. But Aragorn is not only himself the stuff of legend, he also knows a lot of stories and songs in general, as the hobbits find out on their trip to Rivendell where Aragorn serves them as a guide. One example would be his song about Beren and Lúthien (191-93). This song about the love between a mortal and an Elf, published in The Silmarillion, describes the ancient and sad tale of two lovers doomed to be separated by death and this song is entirely applicable to Aragorn's own situation with the immortal Elf Arwen who will choose death on his behalf. It is a moment when the character looks back into the past, whether real or fictional, thus giving Tolkien the possibility of implicitly foreshadowing the future turns of the plot. Aragorn's song of Beren and Lúthien is an instance where fiction becomes reality again because the two are married once Aragorn becomes king. "[T] he tale of their long waiting and labours was come to fulfilment," we read (973), and Tolkien's combinative use of the words tale and fulfilment implies connections to prophecies. This specific tale is of particular interest as it found its inspiration in the author's personal love for his wife Edith (Letters 420). Tolkien fictionalised the real-world love for his wife in his mythology, thus showing once again that there is always some reality in fiction and that authors always have a foundation, be that other tales or their personal life (Shippey, "Appeal of the Pagan" 160). Tolkien reworked his personal reality into his fiction, only for his characters to draw from that as elements of fiction in the fiction itself, making it a reality for them within the overall fiction Tolkien created with his mythology.

The passage which reflects perhaps most clearly the link between fiction and reality is when the Fellowship passes through the Mines of Moria and Gandalf reads from the Book of Mazarbul (321-32). The book is a chronicle of the Dwarfs of Moria and the last pages end with the description of an imminent orc attack. ${ }^{25}$ When the orcs come to attack the Fellowship in a scene closely mirroring the events described in the Book of Mazarbul, different characters from the Fellowship repeat the exact wording that the Dwarfs supposedly used according to the chronicle. This shows that history repeats itself and that there is a close relationship between past and present, showing that it is beneficial to delve into writings

\footnotetext{
${ }^{25}$ It should be noted that history in our common understanding of the word also carries some traces of fiction for nobody knows whether the described events took place as the chroniclers claim and whether they provide the full truth. "History is written by the winners," the saying goes, accordingly, a notion of subjectivity is always present. This is also why we will not look at the Book of Mazarbul as a necessarily non-fictional work inside the fiction. After all, reality and fiction fuse and they are both fictional in one way or another.
} 
of earlier times because they might hold the key to one's own imminent future, the knowledge being much more applicable than people think. Even though this is not a moment where the characters can draw any ancient wisdom from the book, it shows again that there is a certain prophetic nature to the writings from earlier times. But although the characters find themselves in the same situation like the Dwarfs who were slaughtered, their fate does not have to get repeated as well, meaning that their fate is independent from the situations in which they find themselves. There is another outcome possible for them; Tolkien does not simply write a reproduction of the past in his mythology, the characters still have free will and the chance to produce a different outcome of this dangerous situation. Except for Gandalf, who one might say is later resurrected, the Fellowship survive the Mines of Moria, and likewise, Aragorn does not fail in his mission either, as his ancestor Isildur so famously did. The passage in the Mines shows once again that people do have to take action in order to ensure the workings of providence, as we discussed in the previous section. By looking back in history one fears they have seen their future, but the fate of their predecessors does not have to become a reality for them as well. Although situations are repetitive, they are not forcibly prophetic, because the outcomes can be different. "You are not bound to his fate," Arwen points out to Aragorn in Jackson's movie version of The Fellowship of the Ring (01:31:27), an affirmation to which Tolkien would have agreed.

The example no discussion about songs and stories in The Lord of the Rings can avoid is the one of Samwise Gamgee. Sam is a character who is immensely interested in and moved by songs and stories, especially about Elves, and he surprises even his hobbit friends with his knowledge of poetry when they are still in the Shire. In Lothlórien, he gets the idea for the first time that he is actually inside a song, as though fiction encompasses him as a representative of reality (351). He realises that songs and stories are about nothing else than things related in some form or another to reality and he understands that their quest is of such an importance as might be sung about if successful. He thinks about the quest increasingly metaphorically in terms of story and song, especially once he and Frodo come closer to Mordor. At the Stairs of Cirith Ungol, for example, we read:

Still, I wonder if we shall ever be put into songs or tales. We're in one, of course; but I mean: put into words, you know, told by the fireside, or read out of a great big book with red and black letters, years and years afterwards. And people will say: 'Let's hear about Frodo and the Ring!' And they'll say: 'Yes, that's one of my favourite stories. Frodo was very brave, wasn't he, dad?' 'Yes, my boy, the famousest of the hobbits, and that's saying a lot.' (712)

In other words, he wonders whether the account of their adventure will ever be put into a tale, so that others might read or listen to their story just as he likes to do with other people's tales. One could argue of course that Sam seeks fame and glory similar to Beowulf, and that he therefore wants to be put into the legends of 
future days, his memory living on in the fiction about him so to speak. But this is not an accurate comparison, as the hobbit does not want any of the fame and opts for an ordinary life once he is back in the Shire. His association of the quest with fiction is something that provides hope and reinforces his sense of duty towards Frodo and the mission. Sam draws comparisons between the ancient stories he knows and their current situation: "Beren now, he never thought he was going to get that Silmaril from the Iron Crown in Thangorodrim, and yet he did, and that was a worse place and a blacker danger than ours," he tells Frodo (712). This shows that these legends do fulfil a function of encouragement; the two hobbits rely on these stories in order to find the strength to continue their quest. Beowulf does not need such a function of encouragement, as he already is a hero, and one with a power the two hobbits can only dream of. Hence the stories help Sam put things into perspective, to find the hope he needs in order to keep Frodo going. Such a connection between ancient songs and stories and the characters' hope becomes even more evident:

'And we shouldn't be here at all, if we'd known more about it before we started. But I suppose it's often that way. The brave things in the old tales and songs, Mr. Frodo: adventures, as I used to call them. I used to think that they were things the wonderful folk of the stories went out and looked for, because they wanted them, because they were exciting and life was a bit dull, a kind of a sport, as you might say. But that's not the way of it with the tales that really mattered, or the ones that stay in the mind. Folk seem to have been just landed in them, usually - their paths were laid that way, as you put it. But I expect they had lots of chances, like us, of turning back, only they didn't. And if they had, we shouldn't know, because they'd have been forgotten. We hear about those as just went on-and not all to a good end, mind you; at least not to what folk inside a story and not outside it call a good end. You know, coming home, and finding things right, though not quite the same-like old Mr. Bilbo. But those aren't always the best tales to hear, though they may be the best tales to get landed in! I wonder what sort of a tale we've fallen into?'

'I wonder,' said Frodo. 'But I don't know. And that's the way of a real tale. Take any one that you're fond of. You may know, or guess, what kind of a tale it is, happy-ending or sad-ending, but the people in it don't know. And you don't want them to.' (711-12)

This illustrates that people might be thrown into situations (providence) but that they have the choice of not "turning back" (free will). Unlike Beowulf, they do not go looking for trouble, but trouble has found them and they find themselves to be the main protagonists in this story, forced out of passiveness into action. The dialogue shows the reality of fiction and its applicability to real-life problems, ${ }^{26}$

\footnotetext{
${ }^{26}$ It is also noteworthy that Sam is held to be a mighty Elvish warrior by the orcs before he saves
} Frodo from their clutches in The Tower of Cirith Ungol. He seems like one of the Elvish heroes he 
demonstrating its value as a source of wisdom. Stories and songs are something they can both take courage from, and just like the characters inside those stories and songs, the hobbits have to "see things through" even if they do not yet know how everything will end and where their road will lead them, inspiring perhaps others one day to put the deeds of Frodo and Sam into fiction.

Once the Ring is destroyed and the two hobbits are safely back in Rivendell, the symbolic place for song and reflection (Letters 153), their quest is indeed remembered in song just as Sam imagined it. A minstrel sings of "Frodo of the Nine Fingers and the Ring of Doom," taking the reality of the achieved quest into the realm of songs and stories for coming generations to marvel at (954). This acknowledgment of their victory over Sauron and the Ring is something that epitomises a certain circularity of fiction and reality. After all the support from fictional songs and stories, the reality of the Fellowship's success is itself fictionalised, first in Sam's mind, then by a minstrel and later by chroniclers, and thus it can provide hope and encouragement in the form of stories and songs for later people on similar errands, thus giving life to the fiction again, bringing it and its influence back into reality. The characters "shape future legend" and their own lives "are shaped by legendary narratives of the past" (Bolintineanu 267-68). If we compare that to Beowulf, this circularity is somewhat less complete, because the hero himself does not really need the legends as encouragement for his own heroic deeds.

To make such a thing possible, that later people can read up on one's adventures so that these might serve as a source of wisdom for others, it is important that the experiences are written down by the characters involved, as it is done in Apollonius of Tyre for example. This is in fact the "pleasant advice" Bilbo receives from Gandalf; he is supposed to serve only as a "recorder" from that moment on, keeping track of the events and contributing in that manner (270). By writing things down, the characters externalise what they have experienced ${ }^{27}$ and thus make it accessible for others. Bilbo urges Frodo to keep a diary on his quest and Sam suggests that Frodo would need to be locked up in a tower of Minas Tirith, forcing him to start writing before he forgets anything. All this implies that there is almost an obligation to write things down, a serious responsibility towards later generations. This is a point which would of course be dear to Tolkien the medievalist, whose work largely depended on what survived in writing. Isildur having written down his experiences with the Ring proves invaluable to Gandalf and hence to the whole quest and the act of writing the experiences down is in itself something which forces people to remember things and to reflect on them as well. This fictionalisation of reality is important, because it lets songs and stories serve

glorifies so much and in him, their fictional heroism is brought into present reality. This comparison also likens Sam more with the Elves and their ancient wisdom as such.

27 One can consider learning from such fictional accounts to be equal to learning from other people's experiences, similar to reading in history with the difference that the narrated events might only be hypothetical. 
as potential sources of wisdom, inspired by real events, and it should once again be reiterated that the line between fiction and reality is blurry at best. The Red Book of Westmarch that Frodo continues becomes a source of lore, of a more scholarly learning based on facts, and not a book primarily of stories and songs. There will be personal touches by Frodo or his collaborators and we know from Gandalf that the information Bilbo gives in The Hobbit is not fully truthful, but feigned, imagined in parts in order to conceal the real power of the Ring and how he got it (LotR 13). Frodo's book title pays tribute to nearly all of the Fellowship, as his accounts are "supplemented" with "the learning of the Wise" (1027)—and, surprisingly in light of hobbit-culture, we learn that especially the four hobbits engage in a lot of writing after their return. The hobbits become scholars themselves, which is important according to Kraus, "because being heroic ties into being scholarly" in Tolkien's mythology (145). This change can best be seen in Merry and Pippin who become learned librarians in the Shire; they circulate books, they help Frodo redact The Red Book of Westmarch and they seemingly care about the fact that their memories can serve as the basis for wisdom in future times. Having lived through "a very great story" themselves metaphorically, just like Tolkien's son in World War II (Letters 78), their experience makes them wiser.

But even though the adventure of the Fellowship is written down, the memory of it will eventually fade just like everything else. The appendices of The Lord of the Rings make this idea very clear and, as Shippey notes, "prevent any sense of easy, happy closure" because they show their memory's passing into "oblivion" (Road 373). If we compare this point to Beowulf, we realise that Hrothgar tells the hero that his heroic deeds have made him "immortal" (Heaney) in a sense, because his "fame will endure / always and forever"28_ as if the legends about Beowulf will keep the hero alive in the earthly world forever. But the idea of prolonging life via fame is foolish because everything will fade come its day, as the Old English Consolation makes clear (ch. 18). Earthly things like fame are not worth aspiring to, but maybe this forms another attempt at reconciling the two worlds: thanks to his heroic achievements, Beowulf will be remembered on earth in legends, at least for a time far longer than the perception of anyone alive can fathom, and thanks to his Christian faith, he may also get to ascend to heaven, thus living on in both worlds. From such a perspective, the scops' songs in the Old English poem give the impression that Beowulf will join other heroic warriors in legends and that he will be in society's memory for days innumerable. In Tolkien, however, the appendices make it very clear that the memory of the heroes, their fame, is to fade as well. For Sam, stories and songs work as a metaphor for life itself: even though the story continues, its characters come and go, eventually to be forgotten because others take over the leading roles, and this is exactly what happens in The Lord of the Rings. The metafictional moments in Beowulf and the poem as such do not give

28 "Du pe self hafast / dædum gefremed, pæt pin (dom) lyfað / awa to alder," 953-55. 
the impression that the remembrance of the hero will at some point cease. The poem has death as a theme, though without compromising Beowulfs status as a hero, making his heroism stay in the world after his death. Many of the songs and stories in Tolkien are about death too. Even his whole mythology has death as its overarching theme (Letters 284). As Legolas remarks, the songs of the Rohirrim, the people corresponding to Anglo-Saxons in Tolkien's mythology, are "laden with the sadness of Mortal Men" (508). We get the idea that whole species are dying out in Middle-earth, and this notion is even emphasised with the passing of the Third Age. "Swa pes middangeard / ealra dogra gehwam dreoseð ond feallep" (Wanderer 62-63) 29 - it is this awareness which is at the heart of many of the songs and stories interspersed throughout The Lord of the Rings, as for example the songs of the Elves, which embody a certain "sense of remoteness from the world" (Kelly 183). ${ }^{30}$ And this sense of loss and mortality represents another association with the wisdom attainable via songs and stories, in both Old English literature and Tolkien's mythology alike.

Summing up, we can say that songs and stories move on a fine line between reality and fiction and that they are recognised as a common source of wisdom in The Lord of the Rings, encouraging the characters, helping with important decisions, providing, last but not least, insight into the wisdom of long-forgotten days. This connection between wisdom and the vast history of Middle-earth shows to what extent Tolkien's philological profession influenced his mythology. Although the digressive moments in Beowulf are important too, their function is more aimed at emphasising the heroic quality of the main character. The metafictional moments in The Lord of the Rings are also connected to the overall quest, but Tolkien's work places more emphasis on reflection and the wisdom potentially acquired by that road. Situations where fiction is realised or reality fictionalised are common to both texts and show that there is a certain circularity of fiction. Yet while the Old English poem stresses the fictionalisation of Beowulf's heroic achievements, aligning him even more with his great predecessors, Tolkien puts the applicability of old songs and stories into the foreground, as pathways to the ancient world, showing that these characters inside old stories, whether they existed or not, wandered on the same roads.

\section{Information and Counsel as the Currencies of Wisdom}

Now that we are familiar with the philological path to wisdom, let us analyse in how far the characters apply that wisdom in councils about the final achievement of the quest. This section will introduce the idea that wisdom is more important

\footnotetext{
29 "So this middle-earth / each and every day declines and falls."

${ }^{30}$ Songs and stories also portray a kind of cosmogonic knowledge about Middle-earth, especially the songs of the Elves. This seems to be a common association of wisdom in The Lord of the Rings as well.
} 
than Old English heroism, which I will turn to more specifically in the next section. Information and counsel are the currencies of wise people in The Lord of the Rings_-pieces of information are essential to making good decisions for the quest, and this quest in turn becomes a race for information and counsel and for the denial of such to the enemy. The Fellowship's overall success depends on the members' ability to keep their attempt at destroying the Ring low profile. The company's journey is about preventing the enemy from realising what they are doing while at the same time trying to make the best decisions possible according to the counsel they can get. The heroic deeds of Beowulf, on the contrary, only marginally depend on information and counsel.

The most important piece of information is of course that a fellowship has been set up in order to destroy the Ring. The main strategy is to deceive Mordor by keeping Sauron unaware of this threat. As Elrond says, their hope is "in secrecy" (275), and this leads the Fellowship to take routes the enemy would not suspect, such as the path through Moria. This approach of secrecy and avoidance of any direct confrontation with the enemy is of course at odds with the heroic ideals embodied by Beowulf. ${ }^{31}$ While the Council of Elrond consciously opts for secrecy as the main strategy, the Anglo-Saxon poem is designed in such a way as to give the hero every opportunity to prove his heroic valour in battle. Beowulf is a famous warrior, people celebrate him for his courage and he himself is "the most eager for fame" (lofgeornost, 3182) and does not shy away from taking on a dragon all on his own. The problems in Beowulf are met squarely with purely heroic solutions, which means that we have an opposition between the boasting and direct confrontations in the Old English poem and the secrecy required in Tolkien's quest. In contrast, the Fellowship becomes anxious that Sauron might have suspicions and, in obvious cowardice, the company tries its best to conceal its doings. The initial problem obliging Frodo to leave the Shire is that the opposing camp finds and questions Gollum, as Gandalf explains:

Yes, alas! through him the Enemy has learned that the One has been found again. He knows where Isildur fell. He knows where Gollum found his ring. He knows that it is the Great Ring, for it gave long life. He knows that it is not one of the Three, for they have never been lost, and they endure no evil. He knows that it is not one of the Seven, or the Nine, for they are accounted for. He knows that it is the One. And he has at last heard, I think, of hobbits and the Shire. (59, my emphasis; "hobbits" and "Shire" Tolkien's italics)

Tolkien's anaphoric emphasis on the fact that Mordor knows where the Ring is, in other words that he has this particular piece of information, is the core of the problem. If Sauron were to learn that the Ring is to be destroyed, then he could simply use all his forces to guard Mount Doom and all hope would be lost, as

31 The question in how far Tolkien's own heroism distinguishes itself from the Old English foundation will be analysed in the last section. 
Gandalf points out (497). But Sauron cannot imagine that anybody would try to destroy the Ring because he rather fears somebody taking the Ring himself and trying to confront him in open battle, as in an epic poem like Beowulf (497). It is telling, then, that Frodo is fated to carry the Ring as a hobbit. After all, we learn on the first page that hobbits have a talent for remaining out of sight which seems almost magical. While the rest of Middle-earth is fighting, Frodo and Sam are sneaking into Mordor to strike the final yet least violent blow.

But in order to do that, Frodo is dependent on counsellors and guides. When he steps into the spotlight to announce that he will take the Ring to Mordor during the Council of Elrond, he admits that he does not "know the way" (270). This emphasises immediately that Frodo lacks specific pieces of information, here of a geographical nature, to start the quest, let alone to complete it successfully. Such counsellors are first and foremost found in the Fellowship itself, but they also come up at different milestones over the course of their adventure (e.g. Elrond, Galadriel or Faramir)..$^{32}$ It is mainly characters associated with wisdom that carry out such a counselling position in Tolkien's mythology. Elrond is described as the "master of wisdom" and Gandalf as the "wisest of counsellors," for example (1034, 524-25). The case of Gandalf might serve to illustrate the importance of information both for a counsellor and as currency among the wise. The wizard is always on the lookout for new information related to the quest and tries to gather as much news of the enemy's doings as he can, being a member of several council meetings along the road. As a wise character, he knows that this information will be crucial for later counsels and he does not shy away from seeking counsel himself, as his early consultation of Saruman shows. He also trades or shares this information with others, such as Théoden or Denethor, whom he tries to advise based on what he has learned and the piece of information only he and a selected few others can share-namely the discovery of the Ring and the secret plan to destroy it.

But all this information cannot be of any use unless it is thoroughly reflected on and put to practical use for the quest, which brings the concept of geondpencan back into the equation. Let us look at Merry and Pippin meeting Treebeard in Fangorn for illustration. The Entmoot, the Council of Treebeard so to speak, takes ages to arrive at a decision concerning the Ents' potential involvement in the war to come (475-87). Treebeard tells the two hobbits, who grow increasingly impatient, that it does not take the Ents long to decide what to do but that it is the process of hearing and discussing all the available information which takes that much time. The Ents take their time for rumination and this is even reflected in their language, which requires a long time to say anything because it goes to the

\footnotetext{
32 One could consider Gollum a counsellor as well. There is hence an idea of having to accept counsel, in a sense of guidance, in Frodo and Sam's relationship with the creature. Gollum knows "secret ways [into Mordor] that nobody else could find" (715) and this introduces an idea of obligation in the acceptance of counsel, the idea that one cannot always choose one's counsellors.
} 
bottom of anything that it deals with. The problem of the "hasty people,"as Treebeard calls them (475), is that they do not reflect on things long enough before committing to an action and this is something Aragorn also reaffirms when he says that "[t]he hasty stroke goes oft astray" (780). It is clear that the members of the Fellowship cannot always think about and discuss their actions at great lengths, but the general way of the wise, it seems, is to take time for reflection whenever and wherever possible, preferably in a collaborative way during a council. In that light, it is also significant that the first meeting point of the future Fellowship is in Rivendell, the place of reflection, and that the characters seek counsel whenever and wherever they can.

Due to the importance information has for the quest, it is hardly surprising that we find spies to be an important motif in The Lord of the Rings. Saruman seems to employ many birds for such purposes and, along similar lines, the Nazgûl are primarily called Sauron's "winged messengers" (498), stressing even more that the acquisition of news is vital for both sides. Sauron as such is only represented as a great eye, which means that Big Brother is always watching the hobbits, trying to counter all attempts at secret undertakings. The image of the great Eye of Sauron also shows that there is power associated with seeing, with knowing what other people-friend or foe-are doing, because the Eye has the information, and this information is an important currency for decisions. When Frodo is captured by orcs, these think of him as a spy, which shows that both sides take it for granted that information is important for their respective enemies. And information having the importance it has, it is clear that the loss of Saruman to the enemy is a devastating one as he was "deep in [their] councils" (265) and can therefore potentially give a lot of useful information to the other side. According to Elrond, "treason has ever been [the] greatest foe" in their dealings with Mordor (251) and this underscores once again that the danger of good people converting to the bad side - along with the inside knowledge they might have-is a significant factor in The Lord of the Rings. When Isengard has fallen and Gandalf speaks with Saruman, he offers the many-coloured wizard a chance to atone for his ways by helping him and his company "in [their] need" (584). It does not require a lot of imagination to see that it is inside information that Saruman could have revealed, and that this would have put the Fellowship at an advantage in the game of information.

The Fellowship is hence constantly tested with riddles on their road, which is littered with obstacles that need to be overcome. A riddle is the prerequisite for entrance into Moria and the idea of the riddle as such is closely tied with the quest for information. Particular subtasks are called riddles (cf. Aragorn, Legolas, and Gimli's attempt to rescue Merry and Pippin) and their role for the overall quest is pointed out by Aragorn: "[We] must guess the riddles, if we are to choose our course rightly" (416). The word itself goes back to Old English radan meaning "to advise, to counsel, to guide" as Crossley-Holland remarks (x). The etymology clearly associates it with the wise characters in the story because solving riddles is 
what the counsellors do, and what to do with the Ring is the most important riddle in their time. The riddle further epitomises the idea of geondpencan and the quest for information. The wise people try to get new information, which is often represented as a new riddle. They ruminate on it, try to solve it and once they do, they can give new counsel determining future action. This means that the characters in The Lord of the Rings are required to think a great deal on their quest. Their minds are more important than their muscles, and this shows that reflection, and ultimately wisdom, is more important than mere strength.

The riddles in The Lord of the Rings all have immediate practical implications for the characters and are designed by divine providence rather than by humans. This differentiates them from the riddles in Apollonius of Tyre because these are artificially constructed and find their importance only in the role devoted to them by their earthly creator Antiochus. The king's riddle can be seen as a test by humans for humans to figure out who is worthiest of his daughter's hand in marriage: it is the king himself who is testing wisdom and not a higher power as such. The king's riddle only requires reflection and no new information. In Tolkien on the other hand, the riddles are associated with the rumination on new pieces of information gathered on the road, and all of them might prove decisive for the achievement of the quest. The riddles embody the necessity to properly digest all information mentally in order to put one's wisdom to a practical use which will then facilitate important decisions. The biggest riddle is what to do with the Ring, on which Elrond gravely remarks: "None here can [read this riddle for us]. At least none can foretell what will come to pass if we take this road or that" (267). Elrond's remarks show that part of the nature of their practical, real-life riddle is that nobody can safely say which plans will work and which will not because the future is unforeseeable even for the wise.

This aspect of the inability to look ahead with certainty is something that represents a clear limitation to the quest for information as a prerequisite for the destruction of the Ring. But this is also a limitation to all counsel as such because counsel always involves (educated) guesses about what the future is going to be if a particular action is initiated instead of another. Holmes calls this "semantic displacement from present to future" (88). This uncertainty about what the future will hold is probably what leads Gildor to tell Frodo in the very beginning of the story that counsel is "a dangerous gift" (84), for one does not know the future in advance. The Elf is reluctant to give advice and we learn from Frodo that it seems to be commonly known in Middle-earth that one should not ask Elves for advice, as they will "say both no and yes" (84) and Lady Galadriel makes this point even clearer when she says that she is "not a counsellor" (363). 33 The Elves are the wisest species, probably together with the Wizards, yet they do not know the

\footnotetext{
33 One has the impression that Elves such as Elrond or Galadriel seldom give clear advice, but only present new information or lead the characters to think about problems from a new angle. The responsibility of decision remains with the Fellowship.
} 
future either, and therefore they do not claim that their judgments about the future will necessarily prove accurate. As Elrond says when Frodo steps forward to take the Ring to Mordor: "Who of all the Wise could have foreseen it? Or, if they are wise, why should they expect to know it, until the hour has struck?" (272, my emphasis). There are characters, however, who pursue the game of information too earnestly and put too much faith in information they cannot be certain about. This is accordingly no longer represented as wise. This shows that future is an ill counsellor because it can only be inside the characters' heads, imagined not yet real, still fictional in a way. The act of trying to gain knowledge of the future proves disastrous in The Lord of the Rings. Shippey calls these attempts "speculation" in The Road to Middle-earth, pointing out that the ancient meaning of the term is to look into a mirror or a crystal ball (423-26). The characters speculate by use of the palantir, but obtain false information and only come to the "wrong conclusion" (423-26) due to the enemy's power to create "false images" (AmendtRaduege 50). One should add that the use of the palantiri has negative influences on the hope of the characters as well.

The first example I want to adduce for illustration is Denethor. Denethor is a character who was formerly known for his great wisdom and learning as we learn in the appendices (1056-57; App. A), but when he makes his appearance in The Two Towers, he no longer comes across as a particularly wise character. It is owing to his use of the palantir that Denethor has "many ways of gathering news" and can even "read somewhat of the future" (765). He "sees far" (765) with the help of the stone which allows him to gain "great knowledge of things that passed in his realm, and far beyond his borders" (1056; App. A). His use of the palantir leads him so far as to believe that he knows everything he needs to know in order to make his decisions, but he fails to understand that the information he gets from the palantir only represents "fractions of the truth," as Shippey notes (Road 424). He fails to question the source of his knowledge, and is convinced that Frodo and Sam have been captured and Mordor will win, which is why he subsequently loses all hope:

'Pride and despair!' he cried. 'Didst thou think that the eyes of the White Tower were blind? Nay, I have seen more than thou knowest, Grey Fool. For thy hope is but ignorance. Go then and labour in healing! Go forth and fight! Vanity. For a little space you may triumph on the field, for a day. But against the Power that now arises there is no victory ... The West has failed. It is time for all to depart who would not be slaves.'

'Such counsels will make the Enemy's victory certain indeed,' said Gandalf. (853)

It is clear that Denethor's notion of departure is nothing more than a euphemism for the suicide he will later commit. While Denethor looks into the future and despairs, Gandalf's retort is also to look at the future. But contrary to the Steward of Gondor, the wizard emphasises the possibility that action might change the 
course of time. Denethor's despair ("The West has failed. It shall all go up in a great fire, and all shall be ended. Ash! Ash and smoke blown away on the wind!" 852 ) is grounded in the false conclusions he draws from what he sees in the palantir and he erroneously thinks that the image he saw was reality, thinking that Mordor has won and that all resistance is vain. But Denethor is neither omniscient nor a creator-figure knowing what the future may bring and this is why he has no right to despair, because he cannot possibly know in advance whether what he thinks will happen will turn into reality. The wiser Gandalf tries to explain this to Denethor: "[Fighting on] is not despair, for despair is only for those who see the end beyond all doubt. We do not" (269). From such a perspective, his hopelessness is not only foolish, but also a theological sin, as Patrick Curry points out in the documentary J. R. R. Tolkien: Creator of Middle-earth (Pellerin, Creator, 00:15:36), because nobody in Middle-earth is in such a position. He looks into the palantir and is deceived, misinterpreting what he sees, much like Saruman whose treason also goes back to his use of the palantir. As an ideal king, Denethor should be both heroic and wise but he turns out to be neither: by choosing not to fight, he proves cowardice and goes for the only option guaranteeing the success of the enemy. Denethor would have been well advised not to turn down Gandalf's counsel and the ignorance of other people's advice has become his habit of late, as we learn in the appendices (1056-57). "[T] he wise listen to advice," we learn in the Bible (Prov. 12:15), but Denethor seems no longer to figure among them. Like Isildur, like Boromir, or even Beowulf, as we will see, he looks down on counsel that takes away the possibility of learning other people's opinions on the depressing pieces of information. As Gandalf summarises: “The knowledge that [Denethor] obtained was, doubtless, often of service to him; yet the vision of the great might of Mordor that was shown to him fed the despair of his heart until it overthrew his mind" (856).

A quick look at the other uses of the palantiri shows that not a single one of them leads to a good conclusion. Pippin's motive for looking at the stone has nothing to do with the acquisition of news about the enemy's doings. He steals the palantir mainly out of curiosity because Gandalf does not give him enough information. When he looks into the stone, he is soon completely helpless: "Closer and closer he bent, and then became rigid; his lips moved soundlessly for a while. Then with a strangled cry he fell back and lay still" (592). Although he gives away some information to the enemy, the enemy is once again deceived and arrives only at a wrong conclusion. The only information Pippin gives away is a false one; he does not have the Ring and hence the hobbit's use of the palantir has no negative effects for the quest. After that, Aragorn intentionally uses the stone to lead somebody, once again, to a wrong conclusion. He shows himself to Sauron, as the heir of Isildur, which makes Sauron believe that Aragorn now has the Ring 
and will try to overthrow him (cf. Road 423-26). ${ }^{34}$ All of this makes Sauron focus on the military battles ahead while the real danger to him remains in the secrecy of Frodo and the Ring. All in all, the uses of the palantíri show that the wise people in Middle-earth are those who do not meddle with the future; they realise that the quest for information is limited to the extent that even the best of their geondpencan will not accurately predict the future, especially not if the information they obtain is not at all or only partly correct.

A last example of deceptive information is Frodo and Sam's opportunity to look into the Mirror of Galadriel. Before looking into the Mirror, Frodo asks the Lady of Lothlórien whether or not he should use it. Galadriel answers that she cannot help him with his decision, in a typically Elvish manner given Gildor's words earlier, only directing the following words of caution at the two hobbits: "What you will see, if you leave the Mirror free to work, I cannot tell. For it shows things that were, and things that are, and things that yet may be. But which it is which he sees, even the wisest cannot always tell" (362). What the Mirror shows is of a quite perturbing nature, vaguely foreshadowing the plot but also, supposedly, showing the evil turn of events back home in the Shire. Sam cannot take the news about his home and hastily says that he needs to go back. Galadriel criticises Sam's reaction:

'You cannot go home alone,' said the Lady. 'You did not wish to go home without your master before you looked in the Mirror, and yet you knew that evil things might well be happening in the Shire. Remember that the Mirror shows many things, and not all have yet come to pass. Some never come to be, unless those that behold the visions turn aside from their path to prevent them. The Mirror is dangerous as a guide of deeds.' (363, my emphasis)

The Mirror, one could argue, shows a reflection of what the situation of Middleearth will be like if Frodo and the Fellowship were to fail, but it also shows the evil things already happening as a consequence of Sauron's power. The hobbits, though, have to stay in the present and undertake the job at hand, not letting themselves be discouraged by the bad things that are supposedly happening all around them, or about to happen if they do not succeed. The Mirror may show the deceiving future only to the extent that the characters show no agency and give in to despair like the Steward of Gondor. They must not be intimidated by the frightening prospects of their quest-instead, they have to take action and show the kind of bravery any Anglo-Saxon hero would be proud of. Wisdom is to acknowledge the fact that the future cannot be foreseen; it will remain blurry until

\footnotetext{
34 The fact that Gandalf initially wanted to look into the palantir himself is something which falls within the framework of fate and providence again. Gandalf would not have been able to withhold all his knowledge from Sauron and thus it is Pippin's foolishness which prevents the disaster. This shows that folly, in addition to wisdom, also plays a role and that the folly and carelessness of one can lead to the success of a whole quest under the right circumstances.
} 
it comes to pass, and therefore the characters need to be aware that the information they obtain from devices such as the palantíi or the Mirror of Galadriel is deceiving, and does not represent reality (if anything does). They must not trust the "vision[s]" (856) but rather understand their own responsibility, still trying to look ahead on their road but only with a constant awareness of the remaining uncertainty.

There is no foreknowledge in The Lord of the Rings, only premonitions and good gut-feelings that characters like Gandalf seem to possess. It is the wizard's "heart" which tells him early on that Gollum will play a role in the quest (59), and the story could not prove him more right. However, his wisdom forbids him to pretend to know it because he cannot foresee what the higher power might still throw in their way. Just like Frodo, Gandalf cannot "see very far," telling the hobbit: "It may be your task to find the Cracks of Doom; but that quest may be for others: I do not know" (66, my emphasis). It is part of the wizard's wisdom to be aware of such limits. Such premonitions, however, might stem from the character's experiences, or the learning (both historical and legendary) and may sometimes be due to simple common sense, like Sam's mistrust of Gollum. The characters must know that information can be of a deceiving nature and thus joins itself to the game of deception. There are limits to the game of information, pitfalls to be avoided, and this means that the characters should try their best to make sure that the information they gather does not compromise the action they still have to carry out. The quest for knowledge must not go to the detriment of their own agency, no matter how despaired they might become. The game of knowledge, of acquiring information that may be used as a basis for action, is an important one, but it cannot take the place of showing courage and resisting the enemy with wellconsidered action.

We learn from these passages that the characters have to pay attention not to be deceived while joining in the quest for information. This deception can occur not only when characters place their faith in false information, but also when they receive bad counsel. The idea of bad counsel can also be found in Old English literature, of course, most famously with regard to King Æthelred II in The AngloSaxon Chronicles, where the responsibility of a disaster is diverted from the king and blamed instead on the bad counsel he received (Swanton 122-48). Likewise, counsel is not always presented as a good thing in The Lord of the Rings either. If Frodo had listened to Faramir's advice and not trusted Gollum as a guide, would he still have come to Mount Doom? If Gandalf had listened to Saruman's counsel to form an alliance with Mordor, would the enemies of Sauron have stood a chance? Even though Saruman is described as no longer in possession of the wisdom of earlier days, Faramir is a wise character and one should think that his advice would be good. Yet there is also a notion of wilfully bad counsel, the idea of being deceived not by information but by information that is no longer clear but interpreted and biased when received from the counsellor. That leads us to the 
dangers of counsel and the relationship between Théoden and Gríma, king and counsellor.

In Jackson's movie version of The Two Towers, the initial representation of Théoden is the one of an incredibly aged, suffering, and ultimately helpless creature dependent on the help of his counsellors in order to rule (Türme 01:09:47). The impression we get is that the king even has to rely on his counsellor's interference when people talk to him. It is ultimately Gríma they talk to and Gríma who holds the sceptre in Meduseld because the counsellor has effectively replaced the king in all but name. Théoden himself looks ill, even dying, as if the bad counsel he receives from Gríma makes all life in him slowly wither away, just as his kingly responsibilities have long transferred to Gríma and Saruman. ${ }^{35}$ But also in Tolkien's original (506-25), a reliance on bad counsel is represented as an illness causing the king to become dependent on one of his subordinates ("Your leechcraft ere long would have had me walking on all fours like a beast," 519). The imagery of Théoden's healing is marked by a chiaroscuro between the light and hope that Gandalf, clothed in white, brings, and the shadow on Théoden's mind that Gandalf emphasises with the darkness he produces in the hall. This distinction can also be seen in the staffs: the one of Gandalf is white and pure whereas Théoden's staff is black and marked by the counsels of evil. "[T] he tongue of the wise brings healing," it says in the Bible (Prov. 12:18), and with Gandalf there enters a good counsellor into Théoden's halls and one who is able to heal the king. ${ }^{36}$ Contrary to this almost Christ-like interference of Gandalf, we have Gríma "Wormtongue," called a "snake" by Gandalf and constantly dehumanised by the wizard's referral to him with the personal pronoun "it" (513-20). In the Bible, snakes are representatives of human vices and the compound nickname Wormtongue combines the reptile's vice with the organ of speech. Thus his counsels are inherently venomous and evil, spoken with his "forked tongue" (514). What Gríma does counsel is passiveness, contrary to the required agency, as Gandalf points out:

\footnotetext{
35 There is a striking resemblance to Denethor as well here. We learn in the appendices that the Steward is "aged before his time by his contest with the will of Sauron" (1056)—something which introduces again a notion of old age deprived of veneration, because the two characters do not portray any wisdom worthy of it. It is something that negatively affects their potential of good governance, which they no longer carry out.

${ }^{36}$ The counsel that Gandalf brings is of a different kind to Gríma's, of course. When Gandalf enters Meduseld, Gríma calls him a lathspell, Old English for "Ill-news" (513) and the opposite of Old English godspell, which became Modern English gospel. (The Old English spelling is according to the entry in Bosworth-Toller.) In this manner, Gandalf reverses the accusations and attributes these character traits to Grima. It is widely known that Tolkien thought of Gandalf as an angelic figure, a messenger from the West (Letters 159) and as such, it is Gandalf's role to inspire the free people of Middle-earth into resistance, to encourage them. And Gandalf does not merely share bad news with others but he travels much in order to spread hope and to tell people that which they do not necessarily want to hear-the kind of "unpleasant advice" which often proves best (270). He counsels action against the evil rising in the East, even militarily so that the secret part of the plot may work out as hoped.
} 
But when I escaped and warned you, then the mask was torn, for those who would see. After that Wormtongue played dangerously, always seeking to delay you, to prevent your full strength being gathered. He was crafty: dulling men's wariness, or working on their fears, as served the occasion. (521)

Being himself bought by Saruman, Gríma’s “craven” counsels (426) would eventually compromise all hope of a military victory against Sauron, because Rohan and its ally Gondor would slowly but steadily disintegrate.

Consequently, what Théoden needs is the ability to see beyond the ill counsel and the ability to look at the situation without Grima's or Saruman's corrupted lenses. The name Tolkien chose for Théoden's counsellor is Old English for "mask" (Road 302) —a mask because Saruman is behind all this and because Théoden only gets information which is spoiled, tampered with, deceiving, and not as it truly is. He only gets "twisted tales" from Gríma (LotR 514) and his failure lies in the fact that he ascribes too much value to the counsellor's bad advice. It becomes dangerous when a king stops reflecting upon things for himself and Théoden's meeting Saruman at Isengard proves to be another test for the King of Rohan. Although overpowered, Saruman still has his voice, which is a dangerous weapon, as we learn:

Suddenly another voice spoke, low and melodious, its very sound an enchantment. Those who listened unwarily to that voice could seldom report the words that they heard; and if they did, they wondered, for little power remained in them. Mostly they remembered only that it was a delight to hear the voice speaking, all that it said seemed wise and reasonable, and desire awoke in them by swift agreement to seem wise themselves. When others spoke they seemed harsh and uncouth by contrast; and if they gainsaid the voice, anger was kindled in the hearts of those under the spell. For some the spell lasted only while the voice spoke to them, and when it spoke to another they smiled, as men do who see through a juggler's trick while others gape at it. For many the sound of the voice alone was enough to hold them enthralled; but for those whom it conquered the spell endured when they were far away, and ever they heard that soft voice whispering and urging them. But none were unmoved; none rejected its pleas and its commands without an effort of mind and will, so long as its master had control of it. (578)

Saruman's voice urges people to be agreeable without thinking for themselves and not to be mistrustful of what he says. ${ }^{37}$ However, such an approach leads to the loss of one's "mind and will," just as Théoden was effectively replaced as king by his counsellor Gríma. And once Théoden reclaims the responsibility over his decisions, he "live[s]" again and seems old still but now "wise with many winters" as

\footnotetext{
37 As far as counselling ability goes, Gandalf tells Saruman that he should have become a "king's jester ... by mimicking his counsellors" (582). He is also described in a similar snake-like way to Gríma, which condemns his immoral actions.
} 
opposed to the helpless impression he gave earlier (515-16). He combines both wisdom and heroism again, turning into a strong leader for the Rohirrim.

All this shows the pitfalls of counsel whether good or bad in The Lord of the Rings: any kind of counsel presupposes that somebody else interprets a set of information, making his reflection, and potentially also his intentions, the basis for the recommended action. The idea in Tolkien's work is that it is good and wise to listen to counsel and to respect the opinions of others in one's own decisionmaking process, but the deceptions of Grima and Saruman in particular have shown that the ultimate responsibility in the decision-making process must remain with the decider. " [] n doubt a man of worth will trust to his own wisdom," Háma says (511), and it is essential to do a bit of geondpencan oneself: on the situation, the information as such, and the advice from others. If children must solve a riddle on their own after receiving a clue, a king must ruminate and decide himself, even if he has received counsel. The trick seems to be the ability to question advice while at the same time remaining eager to hear it. Counsel, after all, emphasises the interdependence of the characters, who have to walk a fine line between accepting help and advice and being autonomous decision-makers in case there comes a moment when they cannot rely on their trusted advisors anymore. If we look at Frodo or the other hobbits, for example, we realise that they are all reliant on Gandalf or Aragorn as their leaders, as the main decision-makers, but all of them are more or less on their own at times over the course of their quest, which forces them to make their own decisions, consciously in favour of agency and not to its detriment.

The acquisition of new information is an important motif in The Lord of the Rings, as we have seen. Yet even despite possible limitations to the quest for information, it is a game every character in Middle-earth needs to play, whether willingly or not. Far-reaching events such as Sauron's rise to power affect everyone; we see this with the Ents who are involved in the war against their initial thoughts. But the best example of this is Frodo's realisation that the Shire is no longer the place of idyllic beauty and quietness:"

'I knew the danger lay ahead, of course; but I did not expect to meet it in our own Shire. Can't a hobbit walk from the Water to the River in peace?'

'But it is not your own Shire,' said Gildor. 'Others dwelt here before hobbits were; and others will dwell here again when hobbits are no more. The wide world is all about you; you can fence yourself in, but you cannot for ever fence it out.' (83)

The Elf teaches Frodo two things. First, the world is bigger than the hobbit is aware of, both spatially and temporarily and second, even if he neglects what happens outside the borders of the Shire, it will still affect him. Jackson's hobbit proverb, "Keep your nose out of trouble, no trouble will come to you" 
(Gefährten, 00:34:19) ${ }^{38}$ cannot be more effectively refuted than it is with the chapter "The Scouring of the Shire" in the book (998-1020). Once the hobbits return from their journey, they realise that the formerly utopian peace of the Shire has been overtaken by the global problems affecting the whole of Middle-earth. The personal story of Tolkien, who fought in World War I and lost all but one of his close friends only to see his son Christopher drawn into World War II a couple of decades later (Carpenter), shows that problems do not go away if people are ignorant of them, like our hobbits with regard to the "world apart from their perception of reality" (Baltasar 30). The characters can fence themselves in, but they cannot fence the world out, and it is via information and reflection that they best seem to cope with it. In the end it is the four wandering hobbits that beat the ruffians and restore peace in the Shire. Once again, responsibility is required, and it is only fitting that the overarching quest is mainly decided by information. Significantly, those who wander obtain more of it and learn it faster.

Beowulf does not have any comparable quest for information and counsel at its basis and the role of information and counsel is subservient to the primary heroic action the Old English poem is all about. Yet "[w]ise men must hold meetings together," it says in Maxims I ("Ping sceal gehegan / frod wip frodne," 18-19), and therefore we should quickly look at Hrothgar's councils when his realm is plighted by monsters. In lines 171-74 of Beowulf, it says: "Monig oft gesæt / rice to rune; ræd eahtedon, / hwæt swiðferhðum selest wære / wið færgryrum to gefremmanne." 39 These councils, however, are rather ineffective and except for a few useless pagan rituals and the poet's comment on the Danes' unawareness of the Christian God, we do not learn much about them. The council is a failure, showing the helplessness of Hrothgar's people with regard to the action that needs to be taken. We learn how Hrothgar constantly mourns the presence of Grendel without having any clue of what to do about it and he and his councils fall short of a solution for a whole twelve years (170-93). It is only fitting that he willingly accepts Beowulfs "ræd" ("counsel," Heaney, line 278), which embodies overt heroism in its full force. He, as a single man, is to free Hrothgar's people of the monster in an act of heroism. Yet maybe a hero was the only valid answer to their situation considering the fact that his realm was faced with monsters. But then again we could ask ourselves whether it would not have been wiser, though less heroic, to provide him with assistance during his fights. Hrothgar obviously knows about the existence of Beowulf and the hero's powers, so him not having consulted Beowulf of his own initiation might not have been a wise decision

\footnotetext{
${ }^{38}$ To my knowledge, the proverb does not exist exactly like that in Tolkien's original, but might be a rather free adaptation of the following monologue of the Old Gaffer: "Elves and Dragons! I says to him. Cabbages and potatoes are better for me and you. Don't go getting mixed up in the business of your betters, or you'll land in trouble too big for you, I says to him" (24, italics in original).

39 "Many a strong man sat / in secret counsel, considered advice, / what would be best for the brave at heart / to save themselves from the sudden attacks."
} 
either, even though one has to take into account that he must not appear helpless before his people. All of this makes the councils at Hrothgar's court blatantly ineffective, even though the king holds his counsellors in high esteem, like Æschere for example who gets killed by Grendel's mother. A look at Beowulf's own relation to counsel does provide a slightly different picture. Although counsellors surround the hero as well, Beowulf seems to have made his decisions always before these advisors step into the spotlight, giving the counsellors a reaffirming role of his decisions when he decides to take on Grendel. Furthermore, Beowulf's counsellors are generally d'accord with those decisions that help Beowulf showcase his heroism. When the hero decides to fight the dragon all on his own, Beowulf's resolution is firm and independent of any opinion of one of his advisors and were it not for Wiglaf, he would not have succeeded in killing the wyrm ("dragon," 2287). While the hobbits would have failed spectacularly without counsel on their way, Beowulf does not need or want anybody to tell him what to do as a hero, thus emphasising what he can achieve all by himself.

Everything taken together, Tolkien's portrayal of information and counsel suggests a more prominent role in his created world than the two currencies seem to play in Beowulf. While counsel emphasises the interdependence of Tolkien's main characters, the Old English poem portrays a more singular heroism; and the quest for information, or for the denial of it respectively, underlines the importance of reflection, of plans, councils, and sound decisions for the destruction of the Ring in Tolkien's quest. Gold and fame seem to be more valuable currencies in the Old English poem (cf. Baker). In Beowulf, after all, information and counsel play only a minor role for the main character because of his status as a hero.

\section{The Heroification of the Wise and the Demystification of the Heroic}

Moving now to the final section, we will have a look at the interplay of wisdom and heroism and Tolkien's reworking of the Northern theory of courage into The Lord of the Rings. By doing that, Tolkien deemphasises aspects linked to the Germanic understanding of heroism and demystifies the whole idea of a heroism based on fame and achievement in battle, depriving it of the valuation it receives in Old English texts like Beowulf. Tolkien reframes his own heroes into the ordinary and shows by virtue of the hobbits that his heroism stands on a different basis. At the end of the day, it is the wise characters that are looked up to in Middle-earth, and it is they who become heroified in his world.

According to Tolkien himself, perhaps the most famous lines of all Old English verse stem from The Battle of Maldon, lines 312-13, which read: "Hige sceal pe 
heardra, heorte pe cenre, / mod sceal pe mare pe ure maegen lytlað." 40 These lines give a compelling description of the Northern theory of courage, the ideal that was underlying Old English heroic literature. It describes the "unyielding will" of the heroes ("Monsters" 20-21), who find themselves fighting "alongside the gods against the monsters and outer darkness" in a battle "they were always doomed to lose" (Greenwood 183). This battle against evil refers to Ragnarök, an event from Norse mythology which foretells an ultimate battle of good against evil, but other than in Christian eschatology, the evil side will win and therefore, fighting on for the good in such circumstances requires substantially more courage, especially if one considers that there was no heaven or paradise promised to the AngloSaxons, but only the knowledge of having fought for the good side (Author 149-50). The theory of courage represents a courage that is not based on hope (Greenwood 183) and this should sound familiar to readers of The Lord of the Rings. Tolkien himself described the ideal as the "great contribution of early Northern literature" ("Monsters" 20) and reworked it into his own mythology.

Many critics have already pointed to Tolkien's inspiration from the Northern theory of courage before (e.g. Bowman; Author). And indeed Tolkien's concept of heroism seems to be a modification of the theory that does not mirror the original directly. The way Tolkien employs it in The Lord of the Rings is by demystifying the kind of heroism found in poems such as Beownlf. He deemphasises the supernatural physical strength of the heroes while putting the ability to suffer and to endure hardship into the foreground, thus achieving a heroism more familiar to ordinary people. Readers of Beownlf know that the poem's main hero seems like a God-sent warrior, like somebody vastly superior in battle skill capable of defeating the heathen monsters that afflict the court of Hrothgar. He has "thirty / men's strength" ("britiges / manna mægencræft," 379-80) and he is able to win against Grendel without even being armed. His swimming contest with Breca further highlights this idea. What we find in the Old English poem, then, is a representation of the heroic as the extraordinary, the otherworldly or supernatural, as the etymological connection of the word hero to Greek demigods implies (Onions). Tolkien takes this idea and moulds his main heroes back into the ordinary by ascribing the decisive deeds for the destruction of the Ring to plain everyday folk. It is the hobbits who carry the Ring to Mordor, the small and humble people from the Shire who never seek fame or glory in battle but still find the strength to endure the journey. It is the "unforeseen and unforeseeable acts of will, and deeds of virtue of the apparently small, ungreat, forgotten" ones that "represent the unexpected heroism of ordinary men 'at a pinch'," as Tolkien remarked in his Letters (158). It is the ordinary people like him who had to fight in World War I

\footnotetext{
40 "Will shall be the sterner, heart the bolder, spirit the greater as our strength lessens" (Tolkien, "Homecoming," 3). Although I also worked with the edition of The Battle of Maldon in Treharne's anthology, quotations from the text (and all translations) are taken from Tolkien's essay "The Homecoming of Beorhtnoth Beorhthelm's Son."
} 
and such people can surprise many, themselves not least, of their courage when they have no other option. As Elrond points out during the Council, the quest at hand is one where mere heroic battle skills such as those portrayed by Boromir will not suffice to save Middle-earth (269). The "wheels of the world" are moved "by small hands" that have no other choice than to grudgingly accept the situations into which they are thrown (269) and this adequately describes Frodo's situation before setting out to Mordor. The hobbits do not possess any kind of heroic supernatural qualities like Beowulf, but their adventure pays tribute to a modified heroism of its own kind, a heroism independent of physical attributes but based more on the mental struggle in the course of the quest.

The real heroism of the hobbits is of a mental nature, then. This can be shown quite well with Sam and Frodo once they are separated from the rest of the Fellowship. The closer the two hobbits get to Mordor and the Cracks of Doom, the more the themes of imminent death and the obligation of personal sacrifice gain importance. Frodo gradually loses all hope of ever coming out of his mission alive, but he does not yield to the temptation of the Ring until Gollum is there to save the quest. He is different from Denethor, whose lack of hope gives him up to suicidal ideas: Frodo remembers his duty and continues even when he has no hope left. His resolution in front of the Stairs of Cirith Ungol is a good illustration of this:

Frodo raised his head, and then stood up. Despair had not left him, but the weakness had passed. He even smiled grimly, feeling now as clearly as a moment before he had felt the opposite, that what he had to do, he had to do, if he could, and that whether Faramir or Aragorn or Elrond or Galadriel or Gandalf or anyone else ever knew about it was beside the purpose. He took his staff in one hand and the phial in his other. When he saw that the clear light was already welling through his fingers, he thrust it into his bosom and held it against his heart. Then turning from the city of Morgul, now no more than a grey glimmer across a dark gulf, he prepared to take the upward road. (708)

Similar to the Ragnarök ideas, Frodo defies despair and manages to go on without hope. It is the strength of his "will" and his "strength to endure," the two attributes the lembas bread reinforces (936), which mark the Ring-bearer's hobbit-like heroism. As pointed out by John Howe, the journey of the two hobbits is about "finding hope in hopelessness" and continuing with the quest until it is completed (Pellerin, Creator, 00:13:20). Their heroism seems to revolve around the concepts of despair versus hope, and there is a similar description to the one quoted above related to Sam:

But even as hope died in Sam, or seemed to die, it was turned to a new strength. Sam's plain hobbit-face grew stern, almost grim, as the will hardened in him, and 
he felt through all his limbs a thrill, as if he was turning into some creature of stone and steel that neither despair nor weariness nor endless barren miles could subdue.

These lines are only too reminiscent of lines 312-13 from "The Battle of Maldon." 41 It becomes clear, then, that the heroism of the hobbits is one of resistance against all odds, a mental struggle to keep moving one foot in front of the other physically regardless of there being any hope. Tolkien's main heroes are heroes of mental resistance, then. ${ }^{42}$ Although physically weak, Frodo and Sam have tremendous persistence and their being ordinary people provides hope not only for the characters inside Tolkien's work: it might also inspire readers outside of it. In contrast to that, the association of heroism with supernatural strength in Old English literature merely increases the reliance on external help, by giving to understand that heroic deeds are done by heroic people, who are above the ordinary. After the quest is fulfilled and Aragorn steps onto the throne, the new King of Gondor bows to the hobbits which represents a recognition of the courage shown by the small and ordinary people from the Shire. It is a demonstration of respect from a king skilled in battle, directed at a more modern kind of heroism, reworked by Tolkien from the Northern theory of courage.

There are a number of binary oppositions differentiating Old English heroism from Tolkien's reworked form of it. The necessity of secrecy for the Fellowship's quest is contrasted with the boasting culture represented by Beowulf and Byrhtnoth. The Old English emphasis on brute force and physical strength bordering on the supernatural is contrasted with a struggle that is first and foremost mental carried out by those without such physical qualities. Furthermore, the Old English heroic idea of actively seeking fame and glory in battle is contrasted with an idea of obligation to do that which one is fated to do even though one is not interested in fame or glory and seems woefully unfit for the task. This ties into the opposition of fighting and killing for the sake of honour, as well as Tolkien's idea of pity and mercy, the idea of "true courage" consisting in the sparing of a life rather than taking it unnecessarily (Jackson, Hobbit 01:11:40). ${ }^{43}$ Indeed, the ultimate destruction of the Ring is only achieved because Frodo, Sam and Faramir show mercy to Gollum in several key moments, just as Gandalf had recommended in the

\footnotetext{
${ }^{41}$ Hammond and Scull point out in their Companion that the whole chapter "The Choices of Master Samwise" echoes the famous lines from the Old English poem (498).

42 Gandalf repeatedly reminds the characters that it is their courage and their persistence "to the last" (222) which assures their survival, as for example the fact that Frodo is only wounded in the shoulder on Weathertop. "Wyrd often spares / an undoomed man, when his courage endures," it says in Beowulf ("Wyrd oft nereð / unfægne eorl, ponne his ellen deah," 572-73), and in Middle-earth, this mantra seems to apply as well.

43 Although this quote does not figure directly in Tolkien's works but only in Jackson's version, it summarises quite adequately the theme of pity and mercy in Tolkien's mythology.
} 
beginning. At the Cracks of Doom, Sam has a chance to kill Gollum, but his pity and mercy are stronger than his revulsion of the creature:

Sam's hand wavered. His mind was hot with wrath and the memory of evil. It would be just to slay this treacherous, murderous creature, just and many times deserved; and also it seemed the only safe thing to do. But deep in his heart there was something that restrained him: he could not strike this thing lying in the dust, forlorn, ruinous, utterly wretched. He himself, though only for a little while, had borne the Ring, and now dimly he guessed the agony of Gollum's shrivelled mind and body, enslaved to that Ring, unable to find peace or relief ever in life again. But Sam had no words to express what he felt. (944)

Sam spares Gollum's life, lets him live “just a little longer" Jackson, Hobbit 01:11:40), and only therefore Gollum can retake the Ring from Frodo and fall into the lava; his courage to spare a life, even though dangerous for their immediate safety, resulting in the final success of the quest. When Frodo spares Saruman's life after this one tried to stab him in the Shire, the fallen wizard admits that Frodo "ha[s] grown very much" and is now "wise" and "cruel" (1019). And as noted, the name Frodo is inspired by Old English fród, translated in Tolkien's Letters as "wise by experience" (224); in another letter, Tolkien explains that it is Frodo's ability to suffer which gives him "more insight" (191). It is Sam's wise by experience transformation, of having borne and suffered the Ring, which allows him to spare Gollum's life in the decisive moment.

Let us now turn to the interplay of wisdom and heroism. If we concentrate first on Beowulf, we can say that many of the named characters combine both wisdom and heroism in the Old English poem. It is necessary to differentiate between two notions of heroism here. While Beowulf represents the extraordinary and supernatural branch of heroes, we might see a different kind of Old English heroism in the performance of honourable deeds on the battlefield, without having any extraordinary qualities but displaying bravery worthy of the Northern theory of courage. And according to Kaske, such an interplay of wisdom and heroism, which he calls sapientia and fortitudo, ${ }^{44}$ is "the most basic theme in the poem," the references to heroism and wisdom being the climax "of and after each battle" $(423,428)$. In order to analyse this interplay further, together with the idea of good governance, we are going to look at the three good kings ("god cyning," 11, 863 , 2390) according to the poet: Scyld Scefing, Hrothgar, and Beowulf. Scyld Scefing is described as a fierce warrior, as somebody who has won great battles and is praised as a heroic warrior in consequence. Unlike the other supposedly two good kings, Scyld Scefing is not described as a wise character in the passage devoted to him (1-52), which means that his good governance solely relies on his achievements on the battlefield. Hrothgar is the next example and he also wins

44 Notions of Kaske's sapientia include "practical cleverness," "skill in words and works" or a "knowledge of the past," while his definition of fortitudo refers to "physical might and courage" (425). 
great acclaim in battle before ascending the throne. Unlike Scyld Scefing, he is described as wise many times in the poem, his sermon to Beowulf suggesting a firm foundation in Christianity, where much of his wisdom may come from, but he is also generally a reflective character (Kaske 439). Last but not least, Beowulf also combines both wisdom and heroism, even of the extraordinary kind, although the notion of wisdom is only mentioned once he has proved his courage and skill by slaying Grendel (826). Hence it seems as if wisdom is something closely tied to the concept of heroism in the poem, with heroism maybe even being a kind of prerequisite for people to be considered wise. To an extent, this seems to be only logical as Anglo-Saxon rulers would need to excel on the battlefield to ensure kingship and in a world marked by omnipresent suffering and early death, a kind of heroism would be required to even live to old age where associations of wisdom seem more common. In Beowulf, heroism plays a much more important role than it does in Tolkien and it is first and foremost the heroic which is put into legend and mystified. One aspect of wisdom, then, seems to be that decisions in favour of battle and glory are the mark of a wise man in Old English literature. Wisdom seems to be tied closely to heroic success and it is these heroic achievements which ultimately keep populations safe. Neither Hrothgar nor Beowulf gets to reign in periods of peace. Hrothgar's rule sees the occurrence of Grendel and his mother and Beowulf, after a jump of fifty years in the story, rules justly for a time until "the incident with the dragon" (Jackson, Gefährten 00:13:27). And despite their (former) proficiency on the battlefield, neither of them manages to save his realm. Hrothgar's fortitudo, to pick up Kaske's term again, is gone and he relies on the external fortitudo of Beowulf to save his population, noting that Beowulf's supernatural heroism seems to be the only possibility against the monsters. Beowulf later tries to kill the dragon alone, maybe to prove that he, unlike Hrothgar, is not reliant on other people's help to keep his population safe, but just as Hrothgar pointed out to him before, his physical strength would abandon him, even if it is of Beowulf's supernatural kind. This might mean, then, that good governance according to Old English literature hinges on the ruler's ability to display heroism, courage and proficiency in battle, either himself or by external help, rather than any kind of superior wisdom. After all, Hrothgar tells Beowulf that he will make a good ruler after he has killed the two monsters at his court (1840-65), having proven once again his supernatural heroism and thus the supreme quality of governance in the context of his society. In old age, though, the aspect of wisdom seems to become a more characteristic sign of a good ruler than any kind of heroism. This might be due to the fact that strength lessens over time and that might also help explain why many wise characters in Beowulf are former warriors. Ascriptions of wisdom gave poets the chance to point out people's good governance once their primary prerequisite for that, skill on the battlefield, is no longer present. Thus one could see wisdom as a characteristic trait of rulers used by poets 
to maintain a king's reputation once his heroism, mystified and venerated, is steadily fading into oblivion.

The interplay between wisdom and heroism can be found in The Lord of the Rings as well. In Tolkien's mythology, there is also a character who represents more of an Anglo-Saxon ideal of heroism, if not supernatural in physical ability, then at least focused on warfare and glory in battle with all his heart. This character is Boromir. Boromir values traditional heroism with all the fame to be won over the less glorious quality of wisdom required for the plot, and he is proof of the fact that his kind of heroism fails, and is demystified in the process. As Faramir notes, Boromir is a character who is "proud and fearless, often rash, ever anxious for the victory of Minas Tirith (and his own glory therein)" (671) and he proposes to trust in the strength of Men and to use the Ring against Sauron. Yet even after the premise has been established at the Council of Elrond that the Ring cannot be used against Sauron, Boromir remains stubborn in his views. The decision in favour of secrecy does not offer him the possibility to win glory (LibránMoreno 20) and therefore he tries to persuade Frodo of his own plans. He doubts whether those who opted for secrecy at the Council "are wise and not merely timid," thus twisting the actual wisdom in the story to cowardice, and he affirms that "[t]rue-hearted Men ... will not be corrupted" (398). "The fearless, the ruthless, these alone will achieve victory," he continues, asking himself, "[w] hat could not a warrior do in this hour, a great leader?" (398). In his fantasies, he sees himself as a "mighty king, benevolent and wise" after having defeated the forces of Sauron in a "glorious" victory, which allows him to indulge into well-earned fame in battle (398). We can see here that the desire for the Ring, for power, fame and glory, is an ill counsellor, something that deceives people, making them unable to construct reality from an unbiased perspective. The character is too easily ensnared by the Ring and fails to understand that it has to be destroyed and that such a plan requires secrecy rather than overt confrontation on the battlefield, giving the reader to understand that mere heroism like that in Old English literature will not be enough to succeed in their quest. Boromir does not learn from Isildur's example and seemingly does not reflect on the premises established at the Council of Elrond, or is unable to put the results of his reflections into action. As Greenwood remarks comparing Boromir with Frodo, "the stronger shows himself to be the weaker and the weaker stronger" (181). The Ring is "too sore a trial" (LotR 681) for the "traditional heroic figure" and this figure fails its test (Greenwood 181).

The example of Boromir invites a comparison with the heroes from Old English literature, such as Beowulf or Byrhtnoth from The Battle of Maldon. Tolkien published on both poems over the course of his career ("Monsters"; "Homecoming"), these articles being, in fact, "critiques of heroic society, its values and heroes," as Clark explains ("J. R. R. Tolkien and the True Hero" 40). The term ofermod from line 89 of The Battle of Maldon was a term Tolkien awarded specific atten- 
tion. The term as such has been widely interpreted by critics over the years (cf. Gneuss) and Tolkien himself offered "overmastering pride" and heavily criticised Byrhtnoth ${ }^{45}$ for letting the Vikings pass the bridge ("Homecoming" 13). The choice for pride shows a religious connotation to sins and this pride seems to gain control, almost taking on agency itself without well-reflected decisions standing a chance. Tolkien criticises Byrhtnoth for apparently allowing his desire for glory to outweigh his sense of duty towards his people. As Tolkien puts it, "the king wished for glory, or for a glorious death, and courted disaster" (18). This ofermod can be seen in Boromir as well, and the link between the Old English term and his desire for the Ring has long been made by scholars (for example by Forest-Hill). "[W]yrce se pe mote / domes ær deape," Beowulf proclaims ("let him who can / bring about fame before death," 1387-88), and Boromir's actions are based on this sentiment. But as we learn in the Old English Consolation of Philosophy, those who are wise and reflect on fame will understand that it is worthless in the earthly world (ch. 18). Boromir, Byrhtnoth, and Beowulf all die shortly after giving in to pride ${ }^{46}$ their deaths being more or less glorious. Beowulf's death can certainly be seen as a personal sacrifice in order to buy safety for his people with his remaining strength and ability, trying to stay in good memory as a capable ruler. Instead of dying rather unspectacularly from the consequences of old age, he chooses to die a heroic death, a wundordead (Beownlf 3037), but one has to point out that, had it not been for Wiglaf, Beowulf would have been killed and the dragon would have probably survived and could have continued to harass Beowulfs people. From that perspective, the decision to confront the dragon alone is not a sensible one. Byrhtnoth's death was avoidable and the initial decision to invite the Vikings over the bridge to be condemned. The poet of The Battle of Maldon does exactly that in the line following the mention of ofermod. He "should not have done" that ("alyfan landes to fela lapere ðeode," 90), Tolkien translates ("Homecoming" 13). Boromir's failure also has some positive benefits as it makes Frodo understand that he has to break loose from the Fellowship because he cannot trust people blindly. Boromir does not die directly as a consequence of his treason, but Tolkien gives him the opportunity of "regain[ing] honor" by defending Merry and Pippin, thus "dying well" according to the ars moriendi (Forest-Hill 86). What we can draw from all this is that Boromir would not make a good ruler because he places too much importance on the old heroism, on strength and courage, and too little on the wisdom, the sapientia, required in Tolkien's Middle-earth. Although the most eager for fame, he is the one who proves least decisive for the overall success of the

\footnotetext{
45 Tolkien refers to this character as Beorhtnoth, but I will stick to the more typical late West Saxon form Byrhtnoth.

46 As far as Beownlf is concerned, Orchard shows that the word oferhogode in line 2345 mirrors the use of a related noun during Hrothgar's sermon, where the old king warned Beowulf of pride, or "overconfidence" as Orchard translates. His conclusion about this "twin use" is that "Beowulf goes to face the dragon doomed" (260).
} 
quest. His desire for glory and fame cost him the qualities of good governance that seem far more evident in his younger brother.

The differences between Faramir and Boromir are too abundant to be dealt with exhaustively here. Whereas Boromir is described as proud, "delighting chiefly in arms," "fearless and strong" and "caring little for lore, save the tales of old battles," Faramir is "otherwise in mind." He is merciful, "gentle in bearing," "a lover of lore and of music" which is why he is thought to have less courage than Boromir. He does not "seek glory in danger without a purpose" and he is in awe of Gandalf and always trying to learn "from his wisdom" whenever the wizard is in the vicinity (1056; App. A). All this information shows that Faramir is centred more on wisdom than on heroism in battle and that he is reputed to be wiser than his brother although deemed by many less brave. Unlike Boromir, Faramir passes the test of the Ring and does not try to take it from Frodo once the two hobbits walk into his arms. Sam recognises how respectable this decision is and praises Faramir:

Sam hesitated for a moment, then bowing very low: 'Good night, Captain, my lord,' he said. 'You took the chance, sir.'

'Did I so?' said Faramir.

'Yes, sir, and showed your quality: the very highest.'

Faramir smiled. 'A pert servant, Master Samwise. But nay: the praise of the praiseworthy is above all rewards. Yet there was naught in this to praise. I had no lure or desire to do other than I have done.'

'Ah well, sir,' said Sam, 'you said my master had an Elvish air; and that was good and true. But I can say this: you have an air too, sir, that reminds me of, of-well, Gandalf, of wizards.'

'Maybe,' said Faramir. 'Maybe you discern from far away the air of Númenor. Good night!' (682)

Faramir's "quality," or wisdom, is in the decision against his own fame and glory, in understanding that it is wiser to trust the hobbits' way of secrecy. ${ }^{47}$ Sam even compares Faramir to Gandalf, who is one of the wisest inhabitants of Middle-earth

47 In fact, the individual decision in favour or against of claiming the Ring can be seen as a test of wisdom, and therefore of good governance in Middle-earth. Characters like Saruman, Boromir or Denethor fail it, though characters perhaps less directly associated with wisdom like Sam pass the test spectacularly. When he is forced to take the Ring from Frodo after Shelob's attack, he puts the Ring on for a while and we learn how it affects him. He thinks of himself as "Samwise the Strong, Hero of the Age" but his "plain hobbit-sense" prevails and he realises that he does not need anything more than a nice garden to take care of (901). Sam becomes Mayor of the Shire later and it is significant to point out that he does not want any fame or glory when he sets out and that it all "comes unbidden" to him (Clark, qtd. in Timmons 235-36). Sam is an ordinary character, who contributes extraordinary things to the quest by virtue of his normality, later going back to being ordinary with his quiet life in the Shire, thus "pass[ing] out of the Heroic Age" (Bradley 125). His wisdom, as Kraus remarks, is founded in traditional knowledge from poetry and in Bilbo's teachings, which help him in the darkest moments of the quest. 
and as a representative of wizards also of a certain supernatural kind detailed below. Boromir's brother masters the test of the Ring and does not have any fantasies of himself ruling Middle-earth in his glory. He is not tempted by such a desire, unlike the Faramir in Jackson's versions, and he portrays humility as opposed to ofermod. He is "wise enough to know that there are some perils from which a man must flee" (681) and it is this avoidance of direct confrontation to which I would like to draw attention now. Contrary to Boromir, who pans the decision to destroy the Ring as foolishness and cowardice, Faramir links this same decision with wisdom because he understands the necessity of their attempt and he is not blinded by the prospect of fame and glory on the battlefield. "I would not take this thing, if it lay by the highway. Not were Minas Tirith falling in ruin and I alone could save her, so, using the weapon of the Dark Lord for her good and my glory. No, I do not wish for such triumphs, Frodo son of Drogo," Faramir tells the Ring-bearer to his relief (671). It is Tolkien's story that makes a boasting culture like the one from the Old North, as represented by Boromir, seem utterly misguided compared to the wisdom and reflection of avoiding direct confrontations whenever that is possible. As one would expect, Gandalf recognises the potential of good governance in Faramir:

He is bold, more bold than many deem; for in these days men are slow to believe that a captain can be wise and learned in the scrolls of lore and song, as he is, and yet a man of hardihood and swift judgement in the field. But such is Faramir. Less reckless and eager than Boromir, but not less resolute. ${ }^{48}$ (766)

It is possible to combine both wisdom and heroism on the battlefield, and Faramir is the only one in Gondor who unites the twin prerequisites of good governance, with Denethor being desperate and Aragorn not yet having claimed the throne. Faramir makes time to geondpencan before a hard decision and he does not like battle for battle's sake, not loving the glory of battle but only that which battle ultimately defends, namely his home $(672,665)$. This links him again to a more modern adaptation of the Northern theory of courage, as he uses violence only pragmatically and grudgingly, only if necessary and never for the sheer glory and domination possibly resulting from it. Thus Faramir does not become a hero by his action but by his well-reflected inaction, his renunciation of power, which further demystifies the concept of a heroism based on military and physical strength and an eagerness for glory.

In The Lord of the Rings, unlike in Beowulf, it is the wisdom of people which makes characters portray a certain kind of majesty and royalty. It is the wise who

\footnotetext{
48 Although a little far-fetched, the word resolute can be seen as a play on etymology here. In addition to its usual modern meaning of having firmly committed to something, its etymological connection to the verb to solve provides a link to solving problems or riddles (Onions). The first sense does not much differentiate between Boromir and Faramir, though Faramir is the wiser one, he who tries to "guess the riddles" (LotR 416).
} 
are looked up to in veneration and their wisdom makes them seem almost extraordinary and supernatural, which is why one could even say that the wise are heroified. Gandalf would be one such example and the people of Gondor think he "should rule [them] all in the days that follow and in [their] dealings with the Enemy" (862). Gandalf is the wise protector, the Messiah, sent to Middle-earth by the Valar to help protect the free people from the shadows of Mordor. There is a striking comparison between Gandalf and Denethor when Pippin wonders who diffuses more of a kingly air and the wizard is said to be both wiser and more majestic than the Steward of Gondor. Gandalf, as we learn, has a far greater responsibility and influence over Middle-earth than Denethor and this not only refers to the back story of the Istari, the wizards, but also shows that Gandalf is a sort of ruler himself, representing great wisdom, and accordingly good governance, by virtue of his status as a wizard (757). ${ }^{49}$ Therefore, Gandalf seems like somebody from a distant planet, somebody sent to Middle-earth on purpose in order to complete the task he was fated to accomplish. This makes the character otherworldly by extension, supernatural and extraordinary, and the people look up to his great wisdom which is heroified and associated with the extraordinary in the process. He seems "like some wise king of ancient legend" (LotR 226), somebody who not only carries out good governance, but also teaches others the right way to attain it, like a missionary, for example for Théoden's cure. Aragorn is of a similar calibre, someone who reveals great "power and royalty" over the course of the plot (540), and we get an interesting description of him directly after his crowning:

But when Aragorn arose all that beheld him gazed in silence, for it seemed to them that he was revealed to them now for the first time. Tall as the sea-kings of old, he stood above all that were near; ancient of days he seemed and yet in the flower of manhood; and wisdom sat upon his brow, and strength and healing were in his hands, and a light was about him. (968)

Aragorn is "one of the Kings of Men born into a later time, but touched with the wisdom and sadness of the Elder Race" (810). ${ }^{50}$ His wisdom stems from an earlier time and it is this ancient wisdom which is heroified in The Lord of the Rings-it is the ancient wisdom that seems supernatural, though not in a sense linking it to another world but to an older one where "old wives' tales" are still considered important (374). Characters like Gandalf, Aragorn, or even Elrond, whose might "is in wisdom not in battles" (246), are not remnants of a former heroic world, but of a reflective one, a society with "wisdom on [its] brow" (968) and blood on its swords only when unavoidable. In The Lord of the Rings, good governance is first

\footnotetext{
49 As Tolkien explains in his Letters, he uses the term wizard consciously and to the exclusion of terms like sorcerer or magician because of the word's etymological link to wisdom (159).

50 This quote is actually used in a scene when Pippin marvels at the kingly air of Faramir. Faramir seeks inspiration in the kings of old and this is something that links him to Aragorn, who is of that sort.
} 
and foremost about wisdom and not about strength on the battlefield and an unquenchable thirst for glory.

A heroism based on strength and ability in battle is not all unimportant in Tolkien's mythology, of course, and the same wise characters do acknowledge the occasional necessity of military confrontations. Even though Gandalf, Elrond, or Aragorn (though the last to a lesser extent ${ }^{51}$ ) are associated more with wisdom than with warlike heroism, we still have to examine the fact that these characters fight battles too, and the question should be addressed whether their wisdom hinges to some extent on these former achievements in battle. Their wisdom, though, is not a function of their former heroism. It is not linked to battle skills but to both cosmogonic and traditional knowledge fuelled by deep and consistent reflection. The impression we get from The Lord of the Rings is that there can be wisdom in heroism and heroism in wisdom. As Aragorn says about Gandalf's counsels, they were not "founded on foreknowledge of safety, for himself or for others," adding himself that " $[\mathrm{t}]$ here are some things that it is better to begin than to refuse, even though the end may be dark" (441). And Gandalf himself explains in Gondor that "by arms [they] can give the Ring-bearer his only chance, frail though it be" (880), by deflecting Sauron's Eye and by using the latter's sheer inability to see past the threats on the battlefield. The only conscious decision for battle is made after the attack on Minas Tirith, and this is only owing to their attempt to enhance Frodo's chances of secretly coming to the Cracks of Doom; all other battles are defensive in nature. This also shows that a certain level of heroic endeavours on the battlefield is necessary to carry out the quest, even a quest marked by secrecy as much as the Fellowship's. "It is wisdom to recognize necessity," Gandalf proclaims (269), and their attack on Mordor is a purely pragmatic attempt to enhance the likelihood of Frodo's success far away from the battlefield. When they think that Frodo and Sam have been captured, and that their faint hope is vain, they still move into battle. Though from this moment on no longer with the pragmatic purpose in mind but to die themselves a wundordead, dying for a good cause rather than giving up-in the true spirit of the ars moriendi.

Hence, just like his medieval inspirations, Tolkien offers an intricate interplay of wisdom and heroism in The Lord of the Rings. He modifies the Northern theory of courage in order to demystify the particular notion of heroism it represents. Even though his characters still show courage and resilience worthy of the traditional Germanic heroes, the emphasis is drawn away from the extraordinary attributes and skills of the hero, and away from the pursuit of glory towards

\footnotetext{
51 Although Aragorn's achievements in battle are quite important for the plot, he is still a wise character and values his wisdom over his strength in battle. Unlike Boromir, he supports the decision for the secret destruction of the Ring wholeheartedly, and, as pointed out by Ford and Reid, Aragorn's success on the battlefield is needed for the story because he needs to prove his luck in battle in order to be accepted as king by the people of Gondor. Honegger sheds some light on this as well in his essay "Arthur - Aragorn - Ransom: Concepts of Kingship in the Works of Three Inklings."
} 
the plain and unadorned abilities of quite ordinary hobbits. In Middle-earth, the wisdom of the characters is heroified instead and people see potential for good governance in those characters who display this quality. Either explicitly or implicitly, wisdom links these characters to the ancient days, for example to the traditional knowledge of former kings, gained by listening to historical prose such as Beowulf is for our own time and day.

\section{Conclusion}

As we have seen, the representation of wisdom in The Lord of the Rings can reveal a great deal about Tolkien's relation to philology and the way his creation of Middle-earth was affected by his knowledge of Old English literature. Tolkien represents wisdom in such a way that it derives primarily from a knowledge of older times, but his characters are aware at the same time that supposed fiction and tales by the fireside, not unlike Beowulf itself, might reveal a lot of wisdom from the past, which can be highly relevant for the characters' present. The wise characters in Middle-earth do not look down on ancient tales or songs, dismissing them as mere fiction or entertainment for children, but they rather see them as important points of connection between the immediate presence of their practical problems and the potential solutions and hints with which these tales can provide them. All the experience they gain on their road makes them compilers, chroniclers for later times, and this means that they are not only inspired by ancient tales themselves but also promote the ancient wisdom of the future, by putting into fiction what they achieve along their quest. These records in turn may contribute to the wisdom of future generations, helping these people with decisions along their roads. Thus the ancient wisdom of one time reignites the ancient wisdom of a later time, and this means that the circularity of fiction harbours a circularity of wisdom, functioning like a stable source of guidance for the inhabitants of Middle-earth. What is more, wise characters understand the importance of information and counsel as the key currencies for anybody who wants to call himself wise. Tolkien's plot is constructed in such a way as to show the necessity of gaining information and knowledge before the enemy does; wisdom and wise decisions can only be effective if these pieces of information are there. It is similar with counsel, as the novel showcases not only a willingness to listen to advice and recommendations but also the interconnectedness of Tolkien's characters and the requirements of the quest. This urge for counsel deflects the attention away from the individual, all of these currencies suggesting in the process that the quality of being wise is more important than mere heroism in the old sense of the word. This is an aspect which we discussed at great length in the last section. While Beowulf presents a mainly heroic culture, a "shame culture" according to Jones (qtd. in Clark, "The Hero and the Theme" 285), where courage has to be shown on the battlefield, Tolkien's Middle-earth presents heroism in a different light, 
deemphasising the physical and military side to it, moving the notion of heroism into a category that values courage as a purely mental quality, as portrayed especially by those who are physically weak. The application of this interplay of wisdom and heroism to the concept of good governance has shown that Tolkien's real heroes are heroes for their wisdom, while representatives of a purely heroic society, like Boromir, fail spectacularly on the quest, ultimately appearing primitive and ill equipped to carry responsibility.

In Tolkien's Letters, we learn that of all the characters in his created world, the author identified most with Faramir (232). From our philological perspective, that is not especially surprising, as Faramir is described to take great pleasure in learning, especially things of old, and this alone makes him almost an alter ego of Tolkien the medievalist. But Faramir also shares the author's dislike of war and the pursuit of fame and glory on the battlefield. Tolkien's general de-emphasis of the military side of heroism originates in his personal experiences as a recruit in World War I, having witnessed first-hand the misery at the Battle of the Somme (Carpenter). This might be why he presents the action and decisions of the wise people in Middle-earth as alluding to a more pacifist way of understanding the world. Frodo is the ideal embodiment of this once he returns to the Shire: he feels terrible and sad when Saruman and Gríma can only be toppled by the use of military means. While Tolkien's world is more pacifist and pragmatic about violence, the world of Beowulf presents belligerence as the pathway to heroic glory. The path of secrecy, so counterintuitive to any boastful warrior hero, proves to be the wiser choice for the specific requirements of Tolkien's quest, resulting in a situation where Frodo and the Fellowship have to show just as much courage as their peers who confront the forces of Mordor on the battlefields of Middle-earth. In general, there is an emphasis on mercy and pity as opposed to seeking glory in battle. The pillars of fame, glory and domination, which the Ring can bestow and the Old English heroes represent, disintegrate in The Lord of the Rings. It is not possible to destroy the Ring in this very manner of direct confrontation in battle; the characters have to display different qualities, such as wisdom and cunning and an ability to keep their doings discreet. Thus Tolkien's plot is a valuation of wisdom and a devaluation of the Northern theory of courage, a rejection of Old English heroism as it appears in Beowulf. Instead, humility is required and not (overmastering) pride, bumilitas and not superbia, which ultimately shows Tolkien's own, very Catholic, philological contemplations.

Wisdom in Tolkien's mythology seems then to be based on an acceptance of and personal investment in the knowledge of former days, fuelled by constant reflection which may lead to practical help in various difficult situations. It would be interesting to widen the scope of the medieval sources contrasted to Tolkien's works in order to see in what ways this might provide a clearer picture of the author's employment of medieval ideas in his representation of wisdom. Middle English texts would be a good starting point in that regard, but also Old Norse 
literature and the Finnish Kalevala might be interesting sources to keep in mind as Tolkien drew a lot of inspiration from them. This overall idea of wisdom clearly reflects Tolkien's love for his philological profession, showing that there is a point in reading and studying the texts from days long past, creating a world where this kind of knowledge proves crucial for survival. In reality, though, we are given a different picture in which not only philology is struggling to maintain its position in universities but also the humanities as a whole (Delany; Lill). Governmental decisions like the closing of the humanities and social science departments in a number of Japanese universities are just an extreme example of a worldwide trend towards ever more practical knowledge (Dean). Taking such developments into account, it would have pleased Tolkien to know that his love letter to philology, his famous Lord of the Rings, has not yet disappeared under the dust.

I would like to close by presenting the remainder of Gandalf's poem that I quoted at the head of the introduction. While the first two lines show that real worth is not always apparent and that those who wander have not necessarily lost their way, the poem continues as follows:

The old that is strong does not wither,

Deep roots are not reached by the frost.

From the ashes a fire shall be woken,

A light from the shadows shall spring;

Renewed shall be blade that was broken,

The crownless again shall be king. (169-70)

"Estel," an earlier name of Aragorn, who is at the centre of the poem, means "Hope" (1057; App. A) and the character symbolises not only the hope for the return of the King of Gondor but also the hope that Tolkien wanted to see for philology. The character embodies the old and traditional which gets to wear a crown again at the end of The Lord of the Rings, and he gets to rule with traditional "wisdom [on] his brow" (968). There is an image of the dead being resurrected, of something thought useless and lifeless brought to fruition again. Life is lane, we learn from Old English literature, and even though people die their wisdom might not "wither," waiting instead to be rediscovered by philological endeavours. "From the ashes a fire shall be woken," we read, and its light, present and yet remote, illuminates the road ahead.

\section{Works Cited}

Amendt-Raduege, Amy M. "Dream Visions in J. R. R. Tolkien's The Lord of the Rings." Tolkien Studies 3 (2006): 45-55.

Baker, Peter S. Honour, Exchange and Violence in Beowulf. Woodbridge: Brewer, 2013. Anglo-Saxon Studies 20. 
Baltasar, Michaela. "J. R. R. Tolkien: A Rediscovery of Myth." Tolkien and the Invention of Myth: A Reader. Ed. Jane Chance. Lexington: UP of Kentucky, 2004. 19-34.

Bolintineanu, Alexandra. "“On the Borders of Old Stories': Enacting the Past in Beowulf and The Lord of the Rings." Tolkien and the Invention of Myth: A Reader. Ed. Jane Chance. Lexington: UP of Kentucky, 2004. 263-73.

Bonjour, Adrien. The Digressions in Beowulf. Reprint. Oxford: Basil Blackwell, 1965. Medium Ævum Monographs 5.

Bosworth, Joseph. An Anglo-Saxon Dictionary, based on the manuscript collections of the late Joseph Bosworth. Eds. T. Northcote Toller and Alistair Campbell. Oxford: Oxford UP, 1838-1972 (London: Longman, 1838; edited by Toller, 18821898; Toller's Supplement, 1921; reprinted 1966; Campbell's Enlarged Addenda and Corrigenda to the Supplement, 1972). <www.bosworthtoller.com>.

Bowman, Mary R. "Refining the Gold: The Battle of Maldon, and the Northern Theory of Courage." Tolkien Studies 7 (2010): 91-115.

Bradley, Marion Z. "Men, Halflings, and Hero-Worship." J. R. R. Tolkien and the Critics: Essays on J. R. R. Tolkien's The Lord of the Rings. Ed. Neil D. Isaacs and Rose A. Zimbardo. Notre Dame: U of Notre Dame P, 1969. 109-27.

Carpenter, Humphrey. J. R. R. Tolkien: A Biography. 1977. Boston: Houghton Mifflin, 2000.

Clark, George. "J. R. R. Tolkien and the True Hero." J. R. R. Tolkien and His Literary Resonances: Views of Middle-earth. Ed. George Clark and Daniel Timmons. Westport: Greenwood P, 2000. 39-51. Contributions to the Study of Science Fiction and Fantasy 89.

-. "The Hero and the Theme." A Beowulf Handbook. Ed. Robert E. Bjork and John D. Niles. Lincoln: U of Nebraska P, 1997. 271-90.

Coogan, Michael D., ed. The New Oxford Annotated Bible: New Revised Standard Version with the Apocrypha. 4th ed. Oxford: Oxford UP, 2010.

Croft, Janet B., and Edith Crowe. Mythlore Index Plus (Electronic). The Mythopoetic Society, 2015. 09 May 2018 <http://www.mythsoc.org/press/mythloreindex-plus.htm>.

Crossley-Holland, Kevin, ed. Introduction. The Exeter Book Riddles. Revised Edition. London: Penguin Books, 1993. Penguin Classics.

Dean, Alex. "Japan's Humanities Chop Sends Shivers Down Academic Spines." Guardian 26 Sep. 2015. 09 May 2018 <https://www.theguardian.com/highereducation-network/2015/sep/25/japans-humanities-chop-sends-shiversdown-academic-spines $>$.

Delany, Ella. "Humanities Studies Under Strain Around the Globe." New York Times 1 Dec. 2013. 09 May 2018 <http://www.nytimes.com/2013/12/02/us/ humanities-studies-under-strain-around-the-globe.html?_r=1>. 
Dickerson, Matthew T. Following Gandalf: Epic Battles and Moral Victory in The Lord of the Rings. Reprint. Grand Rapids: Brazos P, 2003.

Dubs, Kathleen E. "Providence, Fate, and Chance: Boethian Philosophy in The Lord of the Rings." Tolkien and the Invention of Myth: A Reader. Ed. Jane Chance. Lexington: UP of Kentucky, 2004. 133-42.

Dunning, Thomas P., and Alan Bliss, eds. Introduction. The Wanderer. London: Methuen \& Co Ltd, 1969. Methuen's Old English Library. Poetry.

Eilmann, Julian T. M. "I Am the Song: Music, Poetry, and the Transcendent in J. R. R. Tolkien's Middle-earth." Light Beyond all Shadow: Religious Experience in Tolkien's Work. Eds. Paul E. Kerry and Sandra Miesel. Madison: Fairleigh Dickinson UP, 2011. 99-118.

Ford, Judy A., and Robin A. Reid. "Councils and Kings: Aragorn's Journey Towards Kingship in J. R. R. Tolkien's The Lord of the Rings and Peter Jackson's The Lord of the Rings." Tolkien Studies 6 (2009): 71-90.

Forest-Hill, Lynn. "Boromir, Byrhtnoth, and Bayard: Finding a Language for Grief in J. R. R. Tolkien's The Lord of the Rings." Tolkien Studies 5 (2008): 73-97.

Gneuss, Helmut. “'The Battle of Maldon' 89: Byrhtnoð’s 'Ofermod' Once Again.” Studies in Philology 73.2 (1976): 117-37.

Godden, Malcolm, et al., eds. The Old English Boethius: An Edition of the Old English Versions of Boethius's De Consolatione Philosophiae. 2 vols. Oxford: Oxford UP, 2009.

Greenwood, Linda. "Love: 'The Gift of Death'." Tolkien Studies 2 (2005): 171-95.

Haddan, Arthur W., trans. On the Trinity. Buffalo, N.Y.: Christian Literature Publishing Co., 1887.

Hammond, Wayne G., and Christina Scull, eds. The Lord of the Rings: A Reader's Companion. London: HarperCollins, 2005.

Heaney, Seamus, ed. \& trans. Beowulf: A New Verse Translation. New York: Norton, 2001.

Hibbs, Thomas. "Providence and the Dramatic Unity of The Lord of the Rings." The Lord of the Rings and Philosophy: One Book to Rule Them All. Ed. Gregory Bassham and Eric Bronson. Chicago: Open Court, 2003. 167-78. Popular Culture and Philosophy.

Holmes, John R. "Keeping Counsel: Advice in Tolkien's Fiction." Tolkien in the New Century: Essays in Honor of Tom Shippey. Ed. John W. Houghton, et al. Jefferson, NC: McFarland \& Company, 2014. 87-96.

Honegger, Thomas. "Arthur - Aragorn - Ransom: Concepts of Kingship in the Works of Three Inklings." Proceedings of the 2012 Cerisy Conference (forthcoming). Academia.edu. 1-23. 09 May 2018 <https://uni-jena.academia.edu/Thomas Honegger $>$. 
—. "My Most Precious Riddle: Eggs and Rings Revisited." Tolkien Studies 10 (2013): 89-103.

—. "The Rohirrim: 'Anglo-Saxons on Horseback'? An Inquiry into Tolkien's Use of Sources." Tolkien and the Study of His Sources: Critical Essays. Ed. Jason Fisher. Jefferson, NC: McFarland \& Company, 2011. 116-32.

Irvine, Susan. "The Alfredian Prefaces and Epilogues." A Companion to Alfred the Great. Ed. Nicole G. Discenza and Paul E. Szarmach. Leiden: Brill, 2014. 14370. Brill's Companions to the Christian Tradition 58.

Jackson, Peter, dir. Der Herr der Ringe: Die Gefährten [The Lord of the Rings: The Fellowship of the Ring]. Perf. Elijah Wood and Sean Astin. Warner Home Video, 2001. DVD.

—, dir. Der Herr der Ringe: Die Zwei Türme [The Lord of the Rings: The Two Towers]. Perf. Elijah Wood and Sean Astin. Warner Home Video, 2002. DVD.

- dir. Der Hobbit: Eine unerwartete Reise [The Hobbit: An Unexpected Journey]. Perf. Martin Freeman and Ian McKellen. Warner Home Video, 2012. DVD.

Kaske, R. E. '“Sapientia et Fortitudo' as the Controlling Theme of 'Beowulf." Studies in Pbilology 55.3 (1958): 423-56.

Kelly, Mary Q. "The Poetry of Fantasy: Verse in The Lord of the Rings." J. R. R. Tolkien and the Critics: Essays on J. R. R. Tolkien's The Lord of the Rings. Ed. Neil D. Isaacs and Rose A. Zimbardo. Notre Dame: U of Notre Dame P, 1969. 170-200.

Keynes, Simon. "Alfred the Great and the Kingdom of the Anglo-Saxons." $A$ Companion to Alfred the Great. Ed. Nicole G. Discenza and Paul E. Szarmach. Leiden: Brill, 2014. 13-46. Brill's Companions to the Christian Tradition 58.

-, and Michael Lapidge, eds. and trans. Alfred the Great: Asser's Life of King Alfred and other Contemporary Sources. Harmondsworth: Penguin Books, 1983.

Kimura, Naoji. Der ost-westliche Goethe: Deutsche Sprachkultur in Japan. Bern: Peter Lang, 2006. Deutsch-ostasiatische Studien zur interkulturellen Literaturwissenschaft 2.

Kraus, Joe. "Tolkien, Modernism, and the Importance of Tradition." The Lord of the Rings and Philosophy: One Book to Rule Them All. Ed. Gregory Bassham and Eric Bronson. Chicago: Open Court, 2003. 137-49. Popular Culture and Philosophy.

Langeslag, Paul S. "Lyrics, Riddles, and Wisdom Literature." Old English Literature. Georg-August-Universität Göttingen. Göttingen. 17 Dec. 2015. Lecture.

Lewis, C. S. "The Dethronement of Power." J. R. R. Tolkien and the Critics: J. R. R. Tolkien and the Critics: Essays on J. R. R. Tolkien's The Lord of the Rings. Ed. Neil D. Isaacs and Rose A. Zimbardo. Notre Dame: U of Notre Dame P, 1969. 12-16. 
Librán-Moreno, Miryam. "Parallel Lives: The Sons of Denethor and the Sons of Telamon." Tolkien Studies 2 (2005): 15-52.

Lill, Felix. "Geisteswissenschaften: Angriff auf die freien Denker." Die Zeit Online 20 Apr. 2016. 09 May 2018 <http://www.zeit.de/2016/15/ geisteswissenschaften-abschaffen-japan-gesellschaft-grossbritannien-usa $>$.

Liuzza, R. M., ed. \& trans. Beowulf: Facing Page Translation. 2nd ed. Peterborough: Broadview P, 2013.

Mitchell, Bruce, and Fred. C. Robinson, eds. "The Dream of the Rood." A Guide to Old English. 8th ed. Malden: Wiley-Blackwell, 2012. 264-71.

O'Day, Joseph E. The Ring of Truth: Truth and Wisdom in J. R. R. Tolkien's The Lord of the Rings. Longwood, FL: Xulon P, 2004.

Onions, Charles T., ed. The Oxford Dictionary of English Etymology. Reprint. Oxford: Clarendon P, 1967.

Orchard, Andy. A Critical Companion to Beowulf. Cambridge: Brewer, 2003.

Oxford English Dictionary Online. Oxford: Oxford UP 6 Jan. 2017 <www.oed.com>.

Pellerin, Michael, dir. J. R. R. Tolkien: Creator of Middle-Earth. Kurtti-Pellerin, 2002. DVD.

Pollard, Nick. The Lord of the Rings: J. R. R. Tolkien: Mission, Power, Wisdom and Guidance, Courage. Bletchley: Scripture Union, 2001. Connect Bible Studies.

Roberts, Adam. The Riddles of The Hobbit. Basingstoke: Palgrave Macmillan, 2013.

Ryan, J. S. In the Nameless Wood: Explorations in the Philological Hinterland of Tolkien's Literary Creations. Zurich: Walking Tree Publishers, 2013. Comarë Series 30.

Sheppard, Alice. "A Word to the Wise: Thinking, Knowledge, and Wisdom in The Wanderer." Source of Wisdom: Old English and Early Medieval Latin Studies in Honour of Thomas D. Hill. Ed. Charles D. Wright, Frederick M. Biggs, and Thomas N. Hall. Toronto: U of Toronto P, 2007. 130-46. Toronto Old English Series.

Shippey, Thomas A. J. R. R. Tolkien: Author of the Century. London: HarperCollins, 2001.

-, ed. and trans. "Maxims I." Poems of Wisdom and Learning in Old English. Cambridge: D.S. Brewer; Rowman and Littlefield, 1976. 64-75.

-, ed. and trans. "Maxims II." Poems of Wisdom and Learning in Old English. Cambridge: D.S. Brewer; Rowman and Littlefield, 1976. 76-79.

—. The Road to Middle-earth. 3rd ed. London: HarperCollins, 2005.

-. "Tolkien and the Appeal of the Pagan: Edda and Kalevala." Tolkien and the Invention of Myth: A Reader. Ed. Jane Chance. Lexington: UP of Kentucky, 2004. 145-61.

-. "Wealth and Wisdom in King Alfred's Preface to the Old English Pastoral Care." The English Historical Review 94.371 (1979): 346-55. 
Swanton, Michael, ed. \& transl. The Anglo-Saxon Chronicles. Revised Paperback Edition. London: Phoenix P, 2000.

Timmons, Daniel. "Heroes and Heroism in the Fiction of Tolkien and the Old Norse World: An Interview with George Clark." The Hero Recovered: Essays on Medieval Heroism in Honor of George Clark. Ed. Robin Waugh and James Weldon. Kalamazoo: Medieval Institute Publications (Western Michigan University), 2010. 233-41.

Tolkien, J. R. R. "Beowulf: The Monsters and the Critics." The Monsters and the Critics and Other Essays. Ed. Christopher Tolkien. London: Allen \& Unwin, 1983. 548.

-. "On Fairy-Stories." The Monsters and the Critics and Other Essays. Ed. Christopher Tolkien. London: Allen \& Unwin, 1983. 109-61.

—. The Hobbit. 5th ed. London: HarperCollins, 2006.

—. "The Homecoming of Beorhtnoth Beorhthelm's Son." Essays and Studies 6 (1953): 1-18.

- The Letters of J. R. R. Tolkien. Ed. Humphrey Carpenter with the help of Christopher Tolkien. London: HarperCollins, 2006.

- The Lord of the Rings. Based on 50th Anniversary Edition 2004. London: HarperCollins, 2007.

—. The Silmarillion. Ed. Christopher Tolkien. London: HarperCollins, 1999.

Treharne, Elaine M., ed. \& transl. "Apollonius of Tyre." Old and Middle English, c. 890-1450: An Anthology. 3rd ed. Malden: Wiley-Blackwell, 2010. 275-99.

—. "The Battle of Maldon." Old and Middle English, c. 890-1450: An Anthology. 3rd ed. Malden: Wiley-Blackwell, 2010. 155-69.

—. "Preface to the Translation of Gregory's Pastoral Care." Old and Middle English, c. 890-1450: An Anthology. 3rd ed. Malden: Wiley-Blackwell, 2010. 13-17.

-. "The Seafarer." Old and Middle English, c. 890-1450: An Anthology. 3rd ed. Malden: Wiley-Blackwell, 2010. 60-67.

-. "The Wanderer." Old and Middle English, c. 890-1450: An Anthology. 3rd ed. Malden: Wiley-Blackwell, 2010. 54-61. 